University of Miami Law School University of Miami School of Law Institutional Repository

2012

\title{
Going Rogue: Stop the Beach Renourishment as an Object of Morbid Fascination
}

\author{
Mary Doyle \\ University of Miami School of Law \\ Stephen J. Schnably \\ University of Miami School of Law, schnably@law.miami.edu
}

Follow this and additional works at: https://repository.law.miami.edu/fac_articles

Part of the Environmental Law Commons, Property Law and Real Estate Commons, and the Supreme Court of the United States Commons

\section{Recommended Citation}

Mary Doyle and Stephen J. Schnably, Going Rogue: Stop the Beach Renourishment as an Object of Morbid Fascination, 64 Hastings L.J. 83 (2012).

This Article is brought to you for free and open access by the Faculty and Deans at University of Miami School of Law Institutional Repository. It has been accepted for inclusion in Articles by an authorized administrator of University of Miami School of Law Institutional Repository. For more information, please contact library@law.miami.edu. 


\title{
Going Rogue: Stop the Beach Renourishment as an Object of Morbid Fascination
}

\author{
MARY Doyle* AND STEPhen J. Schnably**
}

Scholarly response to the Supreme Court's decision in Stop the Beach Renourishment, Inc. v. Florida Department of Environmental Protection has focused on the plurality's strong advocacy of a judicial takings doctrine. We take a different tack. While the concept of judicial takings is worthy of serious attention, it is wrong to treat the plurality opinion as an ordinary object of analysis. It is, instead, the emanation of a Court going rogue.

Three basic symptoms of the pathology stand out. First, sleight of hand: The plurality opinion purports to be about an institutional issue - can a state court commit a taking? while slipping in a major rewrite of takings law that would undermine the Court's recent, unanimous effort to clarify it. Second, feigned obliviousness: The plurality opinion conveniently overlooks the Court's federalism jurisprudence even as it would expand the federal courts' power over state law. Third, knowing artlessness: Despite being written as a virtuoso performance-identifying a case the Florida Supreme Court "overlooked"the plurality's treatment of state law betrays surprising naiveté as to how state law is made, though, as it turns out, this seeming naïveté serves the purpose of shifting power within states from legislatures to courts.

While the history and tone of Justice Scalia's close attention to beach access issues makes pique a surprisingly strong candidate for why the plurality went rogue, the more worrying explanation is the willingness of the Court's more conservative members to expand their own power into new areas of state law without the slightest sign of support from the political branches. There is a danger that conservative attacks on courts over decisions on controversial social issues will distract from a more basic problem: If the Court's enforcement of federalism rests on what Justice O'Connor called Congress's "underdeveloped capacity for self-restraint," we suggest that commentary should focus on the Court's own similarly underdeveloped capacity.

* Professor of Law, University of Miami.

** Professor of Law, University of Miami. We are grateful for comments we received from John Leshy, James Brudney, and Louis Mandarini, and for comments on an earlier version from David Abraham, Barbara Brandon, Sergio Campos, Charlton Copeland, Michael Froomkin, Stephen Halpert, Lili Levi, Kunal Parker, and other members of the Miami Legal Theory Workshop. We would like to thank Arthur J.R. Baker, Simeon Genadiev, and Lauren Spahn for excellent research assistance. 


\section{TABLE of Contents}

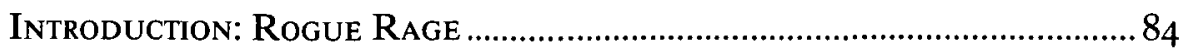

I. THREE TRICKS................................................................................... 9 I

A. SLEIGHT OF HAND ............................................................... 9I

I. The Distraction ..................................................................9I

2. The Victim: Lingle .............................................................. 92

3. The Reveal: A New Takings Standard ..................................95

a. Beach Renourishment and Takings Law ......................95

b. Adding a New Category to Lingle ................................... 98

c. The Impact of the New Category ................................. 100

B. FeIGned Obliviousness ......................................................... 103

I. The Substantive Tension with Federalism ......................... 104

2. The Institutional Tension with Federalism ......................... 107

a. Property Law Making as a Joint Enterprise Between State Courts and Legislatures.......................... 107

b. Dueling Versions of Florida Property Law ................ I I I

C. KNowING ARTLESSNESS............................................................ I I 4

I. The Plurality's Conception of Property Rights................. I I 4

a. Rights and Purposes.................................................... II

b. Rights and Context ..................................................... I I 7

2. Justice Scalia's Guest Turn as a Florida Justice................ 120

II. Two EXPLANATIONS......................................................................... I 125

A. PIQUE ................................................................................ 125

I. Beach and Shoreline Battles ............................................. I25

2. Beach: Blanket or Case by Case?...................................... I 127

B. USURPATION ........................................................................... I 29

CoNCLUSION: ONE VOTE (AWAY) ……………………………………...... 137

\section{INTRODUCTION: ROGUE RAGE}

Is it possible for a state court to commit a taking when it decides the content of property rights under state law? The Supreme Court seemed poised to adopt a "judicial takings" doctrine when it agreed to hear Stop the Beach Renourishment, Inc. v. Florida Department of Environmental

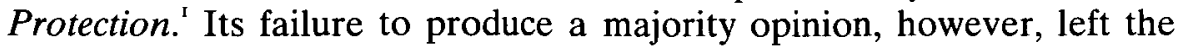
matter open. ${ }^{2}$

I. 130 S. Ct. 2592 (2010). For a typical prediction by one takings scholar, see Ben Barros, What's at Stake in Stop the Beach Renourishment, PropertyProf Blog (July I, 2009), http://lawprofessors. typepad.com/property/2009/o $/$ whats-at-stake-in-stop-the-beach-renourishment.html ("I would guess that Justice Scalia was instrumental in obtaining the cert grant. I predict that the Supreme Court will find a taking in Stop the Beach and that Justice Scalia will write the opinion of the Court."); see also Gary K. 
Scholarly response to Beach Renourishment has largely focused on the plurality's strong advocacy of a judicial takings doctrine. ${ }^{3}$ We take a different tack. The concept of judicial takings is worthy of the serious (and often insightful) attention it has received. ${ }^{4}$ But it is wrong to treat

Odehoff, Florida's Beach Restoration Program Weathers a Storm in the Courts: Stop the Beach Renourishment v. Florida Department of Environmental Protection, 84 FLA. B.J. 10, 19 (20I0).

2. Justice Scalia's plurality opinion, joined by Chief Justice Roberts and Justices Thomas and Alito, accepted the concept of judicial takings. Beach Renourishment, I30 S. Ct. at $2601-02$. Justice Kennedy, joined by Justice Sotomayor, concluded that a state court might violate substantive due process rights in defining property. Id. at 2614-15 (Kennedy, J., concurring in part and concurring in the judgment). Justice Breyer, joined by Justice Ginsburg, argued that since no member of the Court believed the Florida Supreme Court had committed a taking on the facts of the case, there was no need to reach any conclusions about the applicability of the Takings Clause to state courts. Id. at 2618I9 (Breyer, J., concurring in part and concurring in the judgment). Justice Stevens took no part in the decision. Id. at 2597 (syllabus).

3. Among the more useful in understanding the background of the case are Sidney F. Ansbacher et al., Stop the Beach Renourishment Stops Private Beachowners' Right to Exclude the Public, I2 VT. J. Envrl. L. 43 (2010); Craig Anthony Arnold, Legal Castles in the Sand: The Evolution of Property Law, Culture, and Ecology in Coastal Lands, 6I SYRACuSE L. Rev. 213 (201 I); Michael C. Blumm \& Elizabeth B. Dawson, The Florida Beach Case and the Road to Judicial Takings, 35 WM. \& MARY Envtl. L. \& Pol'y Rev. 7I3 (20II). The Vermont LAW Review published a useful set of articles by lawyers for the amici in the case; for an introduction, see L. Kinvin Wroth, Hold Back the Sea: The Common Law and the Constitution, 35 VT. L. Rev. 413 (2010); see also Scott D. Makar, Reflections on Stop the Beach Renourishment v. Florida Department of Environmental Protection, 6I SYRAcuse L. Rev. 28I (20II) (views of Florida Solicitor General). For an extensive analysis of the Florida Supreme Court's opinion, see Sidney F. Ansbacher, Stop the Beach Renourishment: A Case of MacGuffins and Legal Fictions, 35 Nova L. Rev. 587 (2011); see also Donna R. Christie, Of Beaches, Boundaries and SOBs, 25 J. LAND USE \& ENvTL. L. I9 (2009).

Much of the reaction to Beach Renourishment has been critical. See, e.g., J. Peter Byrne, Stop the Stop the Beach Plurality!, 38 Ecology L.Q. 619 (2011); John D. Echeverria, Stop the Beach Renourishment: Why the Judiciary Is Different, 35 VT. L. Rev. 475 (2010); Timothy M. Mulvaney, The New Judicial Takings Construct, I20 YALE L.J. 247 (20II); Daniel L. Siegel, Why We Will Probably Never See a Judicial Takings Doctrine, 35 VT. L. REv. 459 (2010); The Supreme Court, 2009 TermLeading Cases, 124 HARv. L. Rev. 154, 299 (2010); Ian Fein, Note, Why Judicial Takings Are Unripe, 38 Ecology L.Q. 749 (2011). For more supportive views, see Ilya Somin, Stop the Beach Renourishment and the Problem of Judicial Takings, 6 Duke J. Const. L. \& Pub. Pol'y 9I (201I); Robert H. Thomas et al., Of Woodchucks and Prune Yards: A View of Judicial Takings from the Trenches, 35 VT. L. REv. 437 (2010).

Articles that usefully address the procedural questions in bringing a judicial takings claim (and come to different conclusions) include Fein, supra, and Josh Patashnik, Note, Bringing a Judicial Takings Claim, 64 STAN. L. Rev. 255 (2012).

4. The notion of judicial takings has a long history. Some late nineteenth and early twentieth century Supreme Court cases suggested that state courts might violate the Contracts Clause or Takings Clause (or both) in determining state law, but these suggestions seemed abandoned by the 1930s. See Benjamin Fletcher Wright, Jr., The Contract Clause of the Constitution 239-40 (i938); Paul B. Stephan, Redistributive Litigation-Judicial Innovation, Private Expectations, and the Shadow of International Law, 88 VA. L. Rev. 789, 823-30 (2002); Barton H. Thompson, Jr., The History of the Judicial Impairment "Doctrine" and Its Lessons for the Contract Clause, 44 STAN. L. Rev. I373, I433, 1463-66 (1992). More recently the doctrine rested on three pillars. One was Hughes v. Washington, 389 U.S. 290, 296 ( 1967 ) (Stewart, J., concurring) (arguing that if a state court makes "a sudden change in state law, unpredictable in terms of the relevant precedents," it may violate the Takings Clause). The second was Barton Thompson's classic article on the idea of a judicial taking, which thoughtfully explored its history and the arguments for and against it and concluded that it had some merit. Barton 
the plurality opinion as an ordinary object of analysis. It is, instead, the emanation of a Court going rogue. To fail to recognize this is to lose one's way at the outset.

Of course, to call a court a "rogue" is to enter territory largely staked out by conservative pundits and politicians. George Will famously deemed the Florida Supreme Court a rogue in 2000. ${ }^{5}$ Rick Santorum proclaimed the Ninth Circuit a "rogue" and a "pox" for its liberal decisions. ${ }^{6}$ Newt Gingrich's resort to attacks on judicial arrogance and his promise, if elected president, to flout the Supreme Court's Guantánamo decisions drew mainstream disapproval-but they reflected a major national politician's judgment that attacks on the judiciary appeal to many voters. ${ }^{7}$

H. Thompson, Jr., Judicial Takings, 76 VA. L. Rev. I449 (1990) [hereinafter Thompson, Judicial Takings]. The third was Justice Scalia's dissent from the denial of certiorari in Stevens v. City of Cannon Beach; the standard he proposed there turned on whether the state court had relied on a "pretextural" property rule. 510 U.S. 1207, 1214 (1994) (Scalia, J., dissenting from denial of certiorari).

Eduardo M. Peñalver \& Lior Jacob Strahilevitz, Judicial Takings or Due Process?, 97 CoRnell L. Rev. 305 (2012) (examining judicial takings doctrine as a form of judicial insurance with certain moral hazards), is one of the more interesting scholarly treatments since Thompson's. For other analyses of judicial takings, see D. Benjamin Barros, Defining "Property" in the Just Compensation Clause, 63 Fordham L. Rev. 1853 (1995); W. David Sarratt, Judicial Takings and the Course Pursued, 9o VA. L. REv. 1487 (2004); Roderick E. Walston, The Constitution and Property: Due Process, Regulatory Takings, and Judicial Takings, 200 I UTAH L. Rev. 379; J. Nicholas Bunch, Note, Takings, Judicial Takings, and Patent Law, 83 Tex. L. Rev. 1747 (2005).

One can also find intimations of something similar to judicial takings in analyses of areas of law undergoing significant judicial revision. See John Martinez, Taking Time Seriously: The Federal Constitutional Right to Be Free from "Startling" State Court Overrulings, I I HaRv. J.L. \& PUB. PoL'y 297, 34I-46 (1988) (arguing for a constitutional "startlement" claim arising from a Hawaii Supreme Court ruling on water rights of land owners adjacent to streams); Geoffrey R. Scott, The Expanding Public Trust Doctrine: A Warning to Environmentalists and Policy Makers, Io FordHaM ENvTL. L.J. I, 69 (1998) (suggesting that judicial decisions on public trust that come as "a legitimate shock to landowners" should occasion a call on "the public fisc" to support the burden of the change).

5. George Will, Florida's Rogue Court, WASH. Post, Nov. 28, 2000, at A27 ("The U.S. Supreme Court will consider whether Florida's Supreme Court rewrote [state] election law when it moved the reporting deadline to facilitate selective recounts under shifting standards in Democratic strongholds.").

6. GOP Candidates Would Cut Federal Judges' Power, Wash. Post, Oct. 23, 20I I, http://www.washingtonpost.com/politics/gop-candidates-would-cut-federal-judges-power/201 I/1o/23/ gIQA5 4 ZgL_story.html. The Ninth Circuit has long been a target of conservative politicians. See John Schwartz, "Liberal" Reputation Precedes Ninth Circuit Court, N.Y. Times, Apr. 24, 2010, at A33A.

7. For Gingrich's position, see Bringing the Courts Back Under the Constitution: NEWT 2012 Position Paper Supporting Item No. 9 of the 2Ist Century Contract with America (Oct. 7, 20II) [hereinafter NEWT]. The attacks evoked widespread criticism, both conservative, see, e.g., Michael Gerson, Newt Gingrich, The Man Who Knows Too Much, WAsh. Post, Jan. 23, 2012, http://www.washingtonpost.com/opinions/newt-gingrichs-troublesome-lack-of-prudence/2012/01/23/ gIQAslX6LQ_story.html ("This is a presidential candidate promising a constitutional crisis, then arrogantly dismissing the criticism of his recklessness."), and liberal, see, e.g., Erwin Chemerinsky, OpEd., GOP Candidates: Bashing Judges, Threatening Democracy, L.A. TIMEs, Dec. 20, 20I1, http://articles.latimes.com/20I I/dec/20/opinion/la-oe-chemerinsky-fedjudges-20I I 220 ("[T]his year's political thetoric about the courts ... is ... mean-spirited and it shows a stunning ignorance of the 
The charge that the Court is a rogue has not featured prominently in conservative scholarly criticism. ${ }^{8}$ Still, the idea of judicial takings, long championed by commentators advocating stronger protection of property rights, has deep resonance with the charge. Allegations of roguish behavior seem to go hand in hand with judicial takings. One of the Florida Supreme Court justices issued a blistering dissent from the opinion under review in Beach Renourishment, asserting that the majority had "butchered' Florida law" with its "manipulation" of the legal issues, and "simply erased well-established Florida law without proper analysis." For many years the most common articulation of a judicial takings standard was Justice Stewart's 1967 concurrence in Hughes $v$. Washington, in which he proposed that if a state court changed property law in a "sudden" and "unpredictable" way-hardly the attributes we associate with a properly functioning judiciary - that act could constitute a taking. ${ }^{\circ}$ Calling for a judicial takings doctrine in I994, Justice Scalia raised the prospect that a major Oregon Supreme Court holding had invoked "nonexistent rules of state substantive law" to effectuate a "landgrab" running "the entire length of the Oregon coast." "12

The conservative focus on rogue courts is puzzling, to say the least. In recent years the Court, after all, has continued dismantling campaign finance regulation, ${ }^{13}$ read new life into the Second Amendment, ${ }^{14}$ eroded the right to abortion, ${ }^{15}$ raised doubts about the status of independent federal agencies, ${ }^{16}$ and fashioned limits on the Commerce Clause and constraints on the spending power to pose major questions about federal

Constitution and American history."); see also Adam Liptak \& Michael D. Shear, Among Legal Ranks, Shrugs for Gingrich's Tough Talk, N.Y. TIMEs, Dec. 20, 20I I, at A24 ("Reactions vary from amusement to alarm. What is hard to find is approval."); Adam Liptak \& Michael D. Shear, Republicans Turn Judicial Power into a Campaign Issue, N.Y. TIMEs, Oct. 23, 2011, http:// www.nytimes.com/2011/10/24/us/politics/republicans-turn-judicial-power-into-a-campaign-issue.html.

8. For an exception, see Steven W. Fitschen, Impeaching Federal Judges: $A$ Covenantal and Constitutional Response to Judicial Tyranny, Io Regent U. L. Rev. I I I, II8 (I998) ("[A]lthough no federal judge has ever been impeached for rendering unconstitutional opinions, it is historically and constitutionally defensible to begin to do so.").

9. Walton Cnty. v. Stop the Beach Renourishment, Inc., 998 So. 2d IIO2, II2I (Fla. 2008) (Lewis, J., dissenting). He was joined by one other Justice on the seven-member court, Justice Wells.

I0. See Hughes v. Washington, 389 U.S. 290, 296 (I967) (Stewart, J., concurring); see also supra note 4 .

I I. Stevens v. City of Cannon Beach, 5 10 U.S. 1207 , 12 I I (I994) (Scalia, J., dissenting from denial of certiorari).

12. Id. at 1212 . As we show below, moreover, one consistent theme underlying support for a judicial takings doctrine has been the specter of state court "collaboration" with the legislature to undermine property rights on the cheap - without compensation. See infra Part III.B.

13. E.g., Citizens United v. FEC, I30 S. Ct. 876 (2010); Davis v. FEC, 554 U.S. 724 (2008).

14. E.g., District of Columbia v. Heller, 554 U.S. $57^{\circ}$ (2008); McDonald v. City of Chicago, I30 S. Ct. 3020,3044 (2010).

15. E.g., Gonzales v. Carhart, 550 U.S. 124 (2007).

16. E.g., Free Enter. Fund v. Pub. Co. Accounting Oversight Bd., I30 S. Ct. 3138 (2010). 
programs and regulation for years to come. ${ }^{17}$ In the area of takings law, moreover, the concern is equally puzzling. What could possibly account for a fear that rogue state courts need to be reined in before they destroy property rights? The ideology of property rights protection is strongly entrenched in popular opinion and legal culture, and judges are not alien to it. And even if state courts were to disrespect property rights, those rights are highly popular in state legislatures-which can choose to overrule certain common law decisions.

Conventional legal analysis is not going to explain this puzzle. We might drop legal analysis entirely and turn to the Freudian idea of projection to explain conservative attacks on courts as rogues even as the Supreme Court has moved steadily to the right over the last few decades. ${ }^{19}$

We propose, instead, to employ a new approach to scholarly commentary on the Court's opinions, one that refuses to leave the claim that the Court is going seriously amiss entirely to conservative critics. Reflecting the prominence of the theme among conservatives, we take our inspiration from Sarah Palin's campaign memoir of the same title. We do not refer, however, to her proud adoption of "Going Rogue" as a badge of honor, the mark of a down-to-earth politician who refused to stay on message (to the distress of the McCain campaign) and always strained instead to speak common sense to the people. ${ }^{20}$ Nor do we refer

17. E.g., Nat'l Fed'n of Indep. Bus. v. Sebelius, 132 S. Ct. 2566 (2012). Of course, in the view of four of the conservative Justices, this record is not enough. It was, we are told, the failure to invalidate the Affordable Care Act in its entirety-wiping out the chief domestic legacy of a President-that mired the Court in "a vast judicial overreaching." Id. at 2676 (Scalia, Kennedy, Thomas, Alito, JJ., dissenting).

18. A state legislature might run into a takings problem if it overruled a state court decision expanding the definition of property rights, since its action could be said to restrict property rights. But it would likely encounter no such problem overruling a state court decision that had limited property rights; legislative expansions of property rights have not been the prime concern of the Takings Clause. See Lynn E. Blais, Takings, Statutes, and the Common Law: Considering Inherent Limitations on Title, 70 S. CAL. L. Rev. I, 24 (1996) ("The Takings Clause ... act[s] as a shield between private property owners and attempts by the majority to impose the burdens of public benefits on a few individuals.").

19. See Chemerinsky, supra note 7 ("It is ironic that conservatives continue with such attacks even as there is a conservative majority on the Supreme Court and its rulings overall are far more to the liking of conservatives than liberals."). For a similar (and prescient) point in the context of environmental and property law, see Richard J. Lazarus, Changing Conceptions of Property and Sovereignty in Natural Resources: Questioning the Public Trust Doctrine, 71 Iowa L. Rev. 631, 712 (1986) (arguing that, despite conservative critics' attacks on alleged judicial activism in public trust doctrine, courts are for the most part unlikely to favor environmental interests over property rights).

20. Sarah Palin, Going Rogue: An American Life 298-99 (2009); see also id. at 209-339. For another account, see John Heilemann \& Mark Halperin, Game Change: Obama and the Clintons, McCain and Palin, AND the Race of a Lifetime 353-427 (2010). 
to Joe McGinniss' portrayal of her as both carnival sideshow ${ }^{21}$ and rogue elephant. ${ }^{22}$

Rather, drawing on the more playful connotations of the term, ${ }^{23}$ we pay our respects to The Onion Magazine's report in January 201 I that "morbid curiosity" about what would happen if Palin were elected president was leading many voters to support her. ${ }^{24}$ The plurality opinion in Beach Renourishment, we submit, reflects some dangerous tendencies in the Court today. Giving in to a morbid fascination with its breathtaking disregard for basic norms of judicial opinion writing and indulging morbid curiosity about the future direction of a Court in which the plurality opinion could attract five votes turn out to be surprisingly good ways to canvass those dangers.

What does this morbid fascination uncover? As we will show, three basic characteristics stand out. First, the plurality opinion purports to be about an institutional issue - are state courts capable of committing a taking? - while slipping in a major rewrite of takings law. Sleight of hand is not commonly thought a virtue in legislation ${ }^{25}$ or in opinion-writing. ${ }^{26}$

Second, the plurality opinion treats the resolution of the institutional issues as reflecting a deep respect for state autonomy-

21. Joe McGinniss, The Rogue: Searching for the Real Sarah Palin 268-69, 318 (201 1 ).

22. See id. flyleaf (defining "rogue" as: "[a]n elephant that has separated from a herd and roams about alone, in which state it is very savage" (quoting WebsTer's Revised UNABRidGed Dictionary)). For another use of the term-not one we adopt-see Jamal Greene, The Anticanon, 25 Harv. L. Rev. 379, $46_{3}$ (201 I) ("[R]ogue judges [are] incompetent, drunk, or on the make."); Hank Grezlak \& Zack Needles, A Court Gone Rogue, AM. LAwYER, Feb. 2012, at 62 (kickback scandal in Pennsylvania juvenile court). In his interesting account, Greene focuses on what he calls "anticanonical" holdings, widely cited as examples of fundamental error on the Supreme Court's part. These opinions, he argues, share several characteristics. They are "protean," generating multiple, competing explanations for their error; their force as examples to avoid often resides at least in part in the skill of their reasoning; and at least in their time they had some claim to reflect prevailing ethical views (even if we conclude that such views were immoral). Greene, supra, at $460-66$. As we shall see, anti-canonical status would be a step up for the Beach Renourishment plurality.

23. The Oxford English Dictionary gives one definition of rogue as a "mischievous person, esp. a child; a person whose behaviour one disapproves of but who is nonetheless likeable or attractive. Freq. as a playful term of reproof or reproach or as a term of endearment." Rogue, OxFord ENGLISH DictionaRY, http://www.oed.com/viewdictionaryentry/Entry/r66894 (last visited Oct. 2, 2012).

24. Onion News Network, Morbid Curiosity Leading Many Voters to Support Palin, THE ONiON (Jan. 19, 201 I), http://www.theonion.com/section/sarah-palin.

25. Cf. BP Am. Prod. Co. v. Burton, 549 U.S. 84, 99 (2006) ("It is entirely unrealistic to suggest that Congress would proceed by such an oblique and cryptic route.").

26. See, e.g., Massachusetts v. EPA, 549 U.S. 497, 546 (2007) (Roberts, C.J., dissenting) (accusing the majority of sleight of hand); Florida ex rel. Att'y Gen. v. U.S. Dep't of Health \& Human Servs., 648 F.3d I235, I297 (I th Cir. 20II) ("[T]he government's uniqueness argument relies upon a convenient sleight of hand to deflect attention from the central issue in the case ...."). Cf. Rasul v. Bush, 542 U.S. 466, 493-94 (2004) (Scalia, J., dissenting) (criticizing the majority for taking the "oblique course" of pretending not to overrule an earlier case while holding inconsistently with it); Crawford v. Washington, 54I U.S. 36, 59 (2004) (Scalia, J.) ("If [the Court] had meant authoritatively to announce an exception-previously unknown to this Court's jurisprudence - . . it would not have done so in such an oblique manner."). 
refusing to privilege courts over legislatures-while entirely ignoring the Court's federalism jurisprudence as it expands its own power over state property law. Whether reflecting blissful ignorance or feigned obliviousness (we think the latter more likely), the opinion's disregard for a whole line of important cases is quite the spectacle.

Third, the ensuing analysis of state property law that the plurality's test requires it to undertake is written as a virtuoso performanceidentifying as the key holding a case that, weirdly (to use Justice Scalia's term) ${ }^{27}$ the Florida Supreme Court did not even cite. Yet the plurality's treatment of state law is artless, to say the least-but as we shall demonstrate, almost knowingly so.

What accounts for such a memorable performance? Why did the Court "go rogue"? A little morbid curiosity about the mind of the opinion's author suggests one possibility: pique. As we will discuss, Justice Scalia has strong views about how public access to beaches should be determined. Beach Renourishment reminds us that lengthy tenure can breed arrogance alongside the wisdom of experience.

Still, pique hardly explains how the opinion gained four votes and occasioned an elaborate statement by two other Justices in favor of new constitutional supervision of state courts' property determinations. Here is where morbid fascination gives us a glimpse of what the future holds if the plurality's approach to constitutional law becomes predominant. Coming within one vote of a major conservative ruling on new property rights protections, the Beach Renourishment plurality represents a vision of judicial power that legitimizes its use to promote new federal (judicial) intervention into matters previously left largely to the states, without any sign of support from the political branches for doing so.

It should be no surprise that such a vision would be pursued in an opinion marked by sleight of hand, feigned obliviousness, and knowing artlessness. Strengthening the protection of property rights is a goal that no doubt finds real support from many citizens, but it is a goal that competes with other values held by many as well, including the protection and enjoyment of the environment. ${ }^{28}$ For Justices seeking to make a controversial move, stealth must be tempting.

In the past when it stepped out of bounds - when, in Justice Scalia's trenchant formulation, it "was considered by many ... an activist, antiNew Deal Court bent on reducing the power of President Franklin Roosevelt" ${ }^{29}$ - the Court resorted to misleading accounts of its work.

27. Transcript of Oral Argument at 27, 28, Stop the Beach Renourishment, Inc. v. Fla. Dep't of Envtl. Prot., 130 S. Ct. 2592 (2010) (No. 08-I15I) (remark by Justice Scalia) (finding the Florida Supreme Court's failure to cite a case on point "weird").

28. See, e.g., Amy H. Moorman, Let's Roll: Applying Land-Based Notions of Property to the Migrating Barrier Islands, 3I WM. \& MARY ENVTL. L. \& PoL'Y REv. 459, 49I-92 (2007).

29. Morrison v. Olson, 487 U.S. 654,724 (1988) (Scalia, J., dissenting). 
United States $v$. Butler, in which the Court invalidated yet another of Congress's efforts to deal with the Depression, comes to mind: All we do when passing on legislation, the Court said, is "lay the article of the Constitution which is invoked beside the statute which is challenged and... decide whether the latter squares with the former." "Chief Justice Roberts' observation at his confirmation hearing that "[j]udges are like umpires" who apply the rules rather than make them ${ }^{31}$ is more than a little reminiscent of this approach. Like Chief Justice Roberts' assault on the Commerce Clause in the health care case ${ }^{32}$ the plurality's determination to reach the judicial takings question, rather than leave it for another case in which perhaps at least one member of the Court believed a taking to have been effected, reflects a desire to play impresario, not umpire. When all is said and done, the line-up in the rogues gallery is likely to include more than takings cases.

\section{THREE TRICKS}

\section{A. Sleight of Hand}

\section{The Distraction}

As noted, the Supreme Court's grant of certiorari signaled a serious possibility that it might rule that state courts-not just state agencies or legislative bodies - could commit a taking. As it turned out, not a single one of the Justices thought the Florida Supreme Court had committed a taking. What divided the Justices was whether the concept of a judicial taking should be recognized at all.

For the plurality the time was ripe to hold that a state court could indeed commit a taking. It is not sensible, Justice Scalia argued, to determine that there has been no constitutional violation without deciding when one might occur. ${ }^{33} \mathrm{He}$ concluded: "The Takings Clause bars the State from taking private property without paying for it, no

30. 297 U.S. I, 62 (1936).

31. Bruce Weber, Umpires v. Judges, N.Y. Times, July 12,2009 , at WK $\mathrm{I}$.

32. Nat'l Fed'n of Indep. Bus. v. Sebelius, 132 S. Ct. 2566, 2584-93 (20I2); see id. at 2629 n.I2 (Ginsburg, J., concurring in part, concurring in the judgment in part, and dissenting in part) (noting the Chief Justice's agreement that the mandate could be supported under the taxing power); $i d$. ("That being so, I see no reason to undertake a Commerce Clause analysis that is not outcome determinative."). For a critique of the notion that the mandate is beyond Congress's Commerce Clause power, see Arthur J.R. Baker, Fundamental Mismatch: The Improper Integration of Individual Liberty Rights into Commerce Clause Analysis of the Patient Protection and Affordable Care Act, $66 \mathrm{U}$. Miami L. Rev. 259 (20I I).

33. Stop the Beach Renourishment, Inc. v. Fla. Dep't of Envtl. Prot., I3o S. Ct. 2592, 2602 (2010) (plurality opinion); see Nat'l Aeronautics \& Space Admin. v. Nelson, I3 I S. Ct. 746, 767 (201 I) (Scalia, J., concurring in the judgment) (arguing against assessing whether a "hypothetical right has been violated" without "even describing what hypothetical standard should be used"). 
matter which branch is the instrument of the taking." ${ }^{\prime 34}$ In response, Justice Kennedy argued that a judicial takings doctrine would make sense only if state courts had the power of eminent domain, which they do not and should not, since, unlike legislatures, they are not politically accountable. But, he argued, unpredictable changes in the common law of property might violate substantive due process. ${ }^{35}$ Writing separately, Justice Breyer foresaw some potential dangers in a judicial takings doctrine, but saw no need to reach a decision on the facts before the Court. $^{36}$

\section{The Victim: Lingle}

This abstract debate over judicial takings obscured the plurality's sleight of hand. The plurality slipped in a proposed major change to the substantive law of takings which had nothing to do with the ostensible question before the Court. Equally striking, this smuggled-in change would effectively undo a major effort by a unanimous Court to bring clarity to takings law just a few years earlier in Lingle v. Chevron U.S.A. Inc. ${ }^{37}$

Lingle was an effort to rein in an amorphous body of law that posed a real threat of judicial overreach. This threat has dogged regulatory takings law since its inception in Pennsylvania Coal v. Mahon. ${ }^{38}$ There, a coal mining company had deeded surface rights to land on which a house was built, reserving the right to remove all the coal under the land. Later, the Pennsylvania legislature approved the Kohler Act, which forbade the removal of coal if it would cause subsidence of a human habitation. The coal company challenged the statute as a taking. The Court laid out an ad hoc test for resolving the challenge that asked if the regulation had gone "too far." "Here, it concluded, there was little if any public interest in the

34. Beach Renourishment, $130 \mathrm{~S}$. Ct. at 2602 . We note that the plurality's arguments on this point are remarkably weak. The Court has not taken the text particularly seriously in related contexts. See infra note 9I. And it does treat state courts differently from other branches of state government in other contexts. See infra note I02. What was special about the Takings Clause the plurality simply did not make clear.

35. Id. at 26I4-I5 (Kennedy, J., concurring in judgment). Much of Justice Scalia's opinion was taken up with arguing that Justice Kennedy's substantive due process test was so manipulable as to be meaningless. Id. at 2604-05 (Scalia, J.). He also disagreed with the other Justices that a judicial takings doctrine would present insuperable practical difficulties or empower state courts to commit states to spending money on takings of property. Id. at 2607.

36. Id. at $26 \mathrm{Ig}$ (Breyer, J., concurring in part and concurring in the judgment).

37. 544 U.S. 528 (2005).

38. Pa. Coal Co. v. Mahon, 260 U.S. 393 (1922). Before the twentieth century, the Takings Clause was implicated only when the government flooded or otherwise physically invaded privately owned land or ousted its owner without paying compensation. There was no constitutional theory that the right to compensation contained in the Takings Clause could be triggered by regulatory action. See Mugler v. Kansas, I 23 U.S. 623,669 (1887).

39. Pa. Coal, 260 U.S. at 413,415 ("[T] The question depends upon the particular facts [of each case]."). 
fate of "a single private house," but a great adverse impact on the coal company, which lost what was "recognized in Pennsylvania as an estate in land - a very valuable estate."40

Pennsylvania Coal's basic approach - whether the regulation went "too far" - was not a model of clarity. In Penn Central Transportation Co. v. New York City, ${ }^{41}$ the Court took the occasion of a challenge to New York City's Landmark Preservation Law to set out a few lighted buoys on this sea of uncertainty. It highlighted several factors including the "economic impact of the regulation on the claimant," "the extent to which the regulation has interfered with distinct investment-backed expectations," and "the character of the governmental action."

Even so, regulatory takings law admittedly remained an "essentially ad hoc, factual inquir[y]."43 Still worse, only two years later the Court threw another test into the mix, one that later threatened to careen out of control. ${ }^{44}$ In Agins v. City of Tiburon, the Court seemed to borrow from its substantive due process jurisprudence, adding to takings law a means-ends test in which the Court first examined the legitimacy of the government objective and then asked how likely the regulation was to achieve it. ${ }^{45}$

Having blessed such an intrusive test with seemingly little thought, the Court went on over the next decade to formulate two "categorical" tests aimed at marking out zones of certainty. The first, set out in Loretto v. Teleprompter Manhattan CATV Corp., deemed a permanent physical occupation - no matter how minor - a per se taking. ${ }^{46}$ The second, adopted in Lucas v. South Carolina Coastal Council, deemed the complete deprivation of the economic value of property a taking, unless "background principles" of nuisance or property law justify the action. ${ }^{47}$ In practice, neither categorical test did much to clarify takings law.

Lingle was decided in 2005 against this backdrop. The specific occasion for Lingle was the repudiation of Agins" "would-be" doctrinal test. $^{48}$ Lingle itself showed how intrusive means-ends scrutiny of economic regulations can be. Scrupulously following Agins, the trial

40. Id. at $4 \mathrm{I}^{-}-\mathrm{I} 4$.

4I. Penn Cent. Trans. Co. v. New York City, 438 U.S. 104 (I978).

42. Id. at $\mathrm{I} 24$.

43. Id. See, e.g., Mark W. Cordes, Takings Jurisprudence as Three-Tiered Review, 20 J. NAT. ReS. \& ENVTL. L. I, I (2006) (calling takings law before Lingle a "quagmire").

44. Cf. Lingle v. Chevron U.S.A. Inc., 544 U.S. 528, 531 (2005) (“On occasion, a would-be doctrinal rule or test finds its way into our case law through simple repetition of a phrase-however fortuitously coined." (referring to Agins)).

45. 447 U.S. 255,260 ( $\mathrm{r} 980$ ) ("The application of a general zoning law to particular property effects a taking if the ordinance does not substantially advance legitimate state interests, or denies an owner economically viable use of his land." (citations omitted)).

46. 458 U.S. 419,42 I ( 1982$)$.

47. 505 U.S. 1003, 1029 (1992).

48. Lingle, 544 U.S. at 53 I. 
court had essentially conducted a hearing on whether commercial rent control was an effective policy response to rising gasoline prices-a determination a unanimous Supreme Court realized should be the

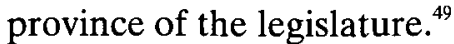

Lingle, however, did more than consign Agins to the dustbin. Lingle sought to reframe regulatory takings law in general, in a way that shrank its concerns to a scope more compatible with democracy at the local and national levels. As Justice O'Connor wrote for a unanimous Court, the central aim of takings law is "to identify regulatory actions that are functionally equivalent to the classic taking in which government directly appropriates private property or ousts the owner from his domain." These actions fell into three categories.

The first, exemplified in Loretto, is a permanent physical invasion of property. Taking over property is practically equivalent to eminent domain, even when the government does not bother with the formal transfer of title (and compensation) that attends it. The second, exemplified in Lucas, is the complete elimination of the property's value. In a society where land is prized largely for its market value, an owner who is left with bare title and undisturbed possession - but no more - has suffered a loss very much like the classic taking, at least where the regulation is not banning a nuisance. The third category, growing out of Penn Central, is where the "magnitude of the regulation's economic impact and the degree to which it interferes with legitimate property interests" 51 requires compensation.

Lingle was plainly written to have bite. And it does. First, its typology of takings is exhaustive. Lingle was all about trimming the list; means-end scrutiny did not make the cut, nor did any other kind of regulatory taking. ${ }^{52}$ Second, Lingle meant to narrow and focus the scope

49. Chevron had challenged as a taking a Hawaiian rent control statute limiting the rent that oil companies could charge dealers leasing company-owned service stations. The purpose of the act was to alleviate the effects of market concentration on gas prices paid by Hawaiian drivers at the pump. The litigation included a day-long bench trial in which the judge heard opposing expert witnesses disagree over whether oil companies would raise wholesale gasoline prices to offset the rent controls imposed by the state, with the perverse result that retail gasoline prices would increase. As Justice O'Connor noted in her opinion for the Court:

The Agins formula can be read to demand heightened means-ends review of virtually any regulation of private property. If so interpreted, it would require courts to scrutinize the efficacy of a vast array of state and federal regulation-a task for which courts are not well suited. Moreover, it would empower-and might often require-courts to substitute their predictive judgments for those of elected legislatures and expert agencies.

Id. at 544

50. Id. at 539 .

51. Id. at 540 .

52. Although Lingle itself did not present it this way, there is arguably a fourth category, involving exactions. Writing for a 5-4 majority in Nollan v. California Coastal Commission, Justice Scalia pronounced it a taking for the state to require the Nollans, as a condition for a permit to build a 
of what remained on the list. Even though the three categories stem from Loretto, Lucas, and Penn Central, the Court confined those tests to actions that are "functionally equivalent to the classic taking," a notably circumscribed approach. Those tests govern to the extent they share the "common touchstone" the Court identified ${ }^{53}$ - the functional equivalence to a classic taking.

In short, Lingle constituted a major event in takings law: a unanimous decision giving a comprehensive account of the area grounded in institutional concerns about the proper role of the courts.

\section{The Reveal: A New Takings Standard}

\section{a. Beach Renourishment and Takings Law}

Seen in light of Lingle, the claim that there was somehow a taking on the facts of Beach Renourishment-whether by the Florida statute or the Florida Supreme Court-is remarkable. ${ }^{54}$ Beachfront property

much bigger house on their oceanfront lot, to grant a public easement across their property to improve access to the public beach. 483 U.S. $825,827-30$ (1987). Citing Agins, the Court found the purpose insufficiently related to the condition. Id. at 834-37. Similarly, in Dolan v. City of Tigard, the Court found a taking where a city granted a store owner permission to expand the store and pave the parking lot on the condition that she dedicate some of her land for a public greenway and pedestrian bicycle path. 5I2 U.S. 374, 388-9I ( I994). The Court faulted the lack of "rough proportionality" between the means and ends. Id. at 39 I. As in Nollan, the Court cited Agins. Id. at 385.

One might think that Agins' demise would cast doubt on these cases. In Lingle, however, the Court expressly distinguished them, not because it wanted to preserve a role for the "substantially advances" test, but because it viewed the exactions cases as:

a special application of the "doctrine of "unconstitutional conditions," which provides that

"the government may not require a person to give up a constitutional right -here the right to receive just compensation when property is taken for a public use-in exchange for a discretionary benefit conferred by the government where the benefit has little or no relationship to the property."

Lingle, 544 U.S. at 547 (quoting Dolan, 5 I 2 U.S. at 385).

The distinction is not entirely persuasive, and one may wonder whether, given Lingle's repudiation of the kind of means-ends scrutiny Nollan and Dolan employed, they should survive Agins' repudiation. See Daniel Pollak, Regulatory Takings: The Supreme Court Tries to Prune Agins Without Stepping on Nollan and Dolan, 33 Ecology L.Q. 925 (2006); Lauren Reznick, Note, The Death of Nollan and Dolan? Challenging the Constitutionality of Monetary Exactions in the Wake of Lingle v. Chevron, 87 B.U. L. Rev. 725 (2007). At the very least, Nollan and Dolan should be applied narrowly rather than broadly. See Timothy Mulvaney, The Remnants of Exactions Takings, 33 Environs Envtl. L. \& Pol'y J. I89 (2010). But see Koontz v. St. Johns River Mgmt. Dist., 2012 WL 1966013 (2012) (cert. granted).

Whether one counts exactions cases as a fourth category, or as a particular application of unconstitutional conditions doctrine, makes no difference to our analysis. What is important is that a unanimous Court in Lingle gave an exhaustive list of the types of regulatory takings.

53. Lingle, 544 U.S. at 539.

54. See Michael B. Kent, More Questions than Answers: Situating Judicial Takings Within Existing Regulatory Takings Doctrine, 29 VA. ENvTL. L.J. 143, 160-66, 167 (201 I) ("Had the legislature or an administrative agency eliminated the right to accretions, Lingle would have governed the analysis and ... probably would have resulted in a decision for the government."). 
owners in the Florida Panhandle claimed that a state project to replenish hurricane-depleted beaches fronting their property amounted to a taking. ${ }^{55}$ Yet their parcels would remain undiminished and the public would gain no rights of access to them. The only obvious difference would be that after the restoration project, there would be a 75 -foot public sand beach fronting the landowners' property. Having been replenished at public expense, this beach would be open to the public.

In practical terms, the presence of an adjacent public beach seemed to form the crux of the petitioners' objection. ${ }^{56}$ However objectionable this prospect might be to the landowners, it would seem far from "functionally equivalent to the classic taking in which government directly appropriates private property or ousts the owner from his domain," in Lingle's terms. There was no physical invasion (Loretto); the property had significant value (Lucas); and the beach restoration program had been in effect for decades as a way to preserve a public resource deemed vital under Florida's constitution (Penn Central).

The legal argument put forth was of a different sort, however. The property owners claimed that Florida had taken two specific, recognized rights without compensation. The first was the right of accretion. Beaches can build up (or erode) gradually over time, a process called accretion (or reliction). ${ }^{57}$ When accretion occurs, the sandy beach expands seaward, pushing the mean high water line - the point the high tide reaches on average-seaward as well. This process has practical significance for beachfront property owners. Florida law sets the mean high water line as the boundary between privately owned beachfront land and the public part of the beach. Thus, if there is accretion, the boundary between the private and public portions of the beach will shift seaward. Consequently, under Florida law, where there is accretion to the shoreline, a beachfront property owner's land expands in size..$^{58}$

55. Where the beach has eroded significantly over time through either process, local governments tend to support beach restoration to protect tourism and coastal properties. See ERIC C.F. BIRD, BEACH MANAGEMENT 134-37 (1996).Various techniques may be used; a common one involves dredging sand from further out the shore and depositing it on the wet sand portion of the beach. See id. at I62-88; C.W. Finkl \& H.J. Walker, Beach Nourishment, in ENGINEERED CoASTS I, I-22 (Jiyu Chen et al., eds., 2002). Though beach nourishment is a widely accepted technique, see H.J. Walker \& C.W. Finkl, Beach Renourishment: Case Studies, in ENGINEERED COASTS, supra, at 56, it can be expensive and may have adverse environmental impacts. See BIRD, supra, at 20I-I0; KARL F. Nordstrom, BeACH AND Dune Restoration 24-36 (2008). The plaintiffs in Beach Renourishment do not, however, seem to have been motivated by these concerns.

56. Transcript of Oral Argument at 9-14, 46, Stop the Beach Renourishment, Inc. v. Fla. Dep't of Envtl. Prot., 130 S. Ct. 2592 (2010) (No. 08-II5I) (colloquy about the hypothetical prospect of the state allowing a hot dog vendor to operate on beach behind petitioners' houses).

57. For a thoughtful account of the history of accretion and avulsion as legal terms, together with an assessment for their relevance in the face of climate change, see Joseph L. Sax, The Accretion/Avulsion Puzzle: Its Past Revealed, Its Future Proposed, 23 TuL. ENvTl. L.J. 305 (2010).

58. Walton Cnty. v. Stop the Beach Renourishment, Inc., 998 So. 2d I I02, I I I I, 1 II 2-I4 (Fla. 
Of course changes are not necessarily gradual. The contours of a beach can also be dramatically changed overnight by major events like hurricanes, a process called avulsion. Under Florida law, as under many other states' laws, when avulsion occurs the boundary remains unchanged. ${ }^{59}$

The second claimed taking was of an alleged right that the property have direct contact with the water. Once the restoration was completed, there would now be a publicly owned dry sand beach between their property and the Gulf. Their access (physical and visual) to the water would continue unhindered, but the water would no longer lap up against their property at high tide.

The plaintiffs first charged that it was the Florida Beach and Shore Preservation Act $^{60}$ that took these two rights. In connection with the restoration of the beach, the statute would permanently fix the line between the public and private portions of the beach at what had been the mean high water line over the last two decades. With the boundary line now immovable, the property owners would lose any chance of gaining new land due to accretion. ${ }^{61}$ This loss, they claimed, was a taking. Equally a taking, they claimed, was the loss of direct contact with the water, now that a public dry sand beach would stand between them and the water.

The Florida Supreme Court rejected the plaintiffs' claim. It was not that the statute in fact preserved the alleged rights. Rather, the court ruled after an extensive analysis of Florida common law that the property owners had no such rights in the first place. In the context of beach restoration, the right of accretion was a contingent right, the court held, not a full property right. It also ruled that the right of contact with the water was merely ancillary to the beachfront owner's right of access to the water, which remained unimpeded. ${ }^{62}$

The property owners now asserted that the Florida Supreme Court itself had taken their property by finding that the common law did not recognize the rights they claimed the Florida statute had taken. They first petitioned the Florida Supreme Court for rehearing, which summarily denied the motion, ${ }^{6}$ and then sought review by the Supreme Court.

The Court did not endorse a judicial takings doctrine, but as noted the plurality readily took on that task. It began with a nod to Lingle's

2008).

59. Id. at III4

60. I96I Fla. Laws ch. 61-246 (codified as amended at Fla. Stat. §§ 161.01 I-.45 (2012)).

6I. Of course, accompanying the loss of the benefit accretion was the loss of the risk of erosion over time. With erosion, a property owner's house might end up on the sandy beach a short distance from the water.

62. Walton Cnty., 998 So. $2 \mathrm{~d}$ at $1 \mathrm{I}$ I8-20.

63. Walton Cnty. v. Stop the Beach Renourishment Inc., No. SCo6-I447, 2008 Fla. LEXIS 2483, at * I (Fla. Dec. I8, 2008). 
three categories. ${ }^{64}$ But it went on to stake out another category not mentioned in Lingle: elimination of an established property right. As Justice Scalia put it, "[i]f a legislature or a court declares that what was once an established right of private property no longer exists, it has taken that property." 6 s

\section{b. Adding a New Category to Lingle}

Although the plurality did not acknowledge it, there is no doubt that its proposed test amounts to an addition to Lingle and the Court's case law. ${ }^{66}$ Three features of this new category stand out. First, it wholeheartedly embraces "conceptual severance." In this approach, the impact of the regulation on the property owner is not measured against the parcel as a whole, or its value as a whole. The owner's rights are broken down into the sticks in the bundle, and it is the impact of the regulation on a given stick that counts. ${ }^{67}$ A conceptual severance approach makes the "denominator" smaller (at least conceptually) and could trigger many more Lucas-based claims of a complete elimination of value, even where the overall value of a parcel of land remained relatively intact. In 1987 , the Court firmly rejected this approach, ${ }^{68}$ holding

64. Stop the Beach Renourishment, Inc. v. Fla. Dep't of Envtl. Prot., I30 S. Ct. 2592, 2601 (2010).

65. Id. at 2602 (emphasis omitted); see id. at 2601 ("States effect a taking if they recharacterize as public property what was previously private property."). Cf. Luke A. Wake, Pacific Legal Found., Can States Redefine Property Rights?, PLF LiberTy Blog, (Jan. 20, 2010), http://plf.typepad.com/plf/20Io/oI/can-states-redefine-property-rights.html (arguing, while Beach Renourishment was pending, that the Court should add another category to the Lingle catalog).

66. The plurality presented this proposed new category-elimination of an established property right-as if it were simply taking note of a prior case, Webb's Fabulous Pharmacies, Inc. v. Beckwith, 449 U.S. $155,163-65$ (1980). But there is no doubt that in fact, the plurality's proposed test amounts to an addition to Lingle and the Court's case law. For one thing, one can search in vain within Lingle's summary of takings law for any hint of such a category. Equally important is Lingle's admonition that takings are actions that are practically equivalent to physically ousting a property owner or taking over the owner's ownership of the property. Webb's Fabulous Pharmacies fits that admonition quite well: Under the Florida statute at issue in that case, individuals forfeited all interest earned on funds deposited in court. Id. at I6r; see Brown v. Legal Found. of Wash., 538 U.S. 216 (2003); Phillips v. Wash. Legal Found., 524 U.S. 156 (1998). Beach Renourishment-the occasion for the recognition of this new category-involved nothing like the alleged deprivation in Webb's Fabulous Pharmacies. Beachfront property owners were not ousted from their land, nor was their title threatened; nor was any easement created on their land.

67. See Richard A. Epstein, Taking by Slivers, NAT'L L.J., May 6, 2002, at A2I (criticizing the Court's decision in Tahoe-Sierra Pres. Council, Inc. v. Tahoe Reg. Planning Agency, 535 U.S. 302, 33 I (2002): "[Justice] Stevens fell into the regrettable trap of assuming that the test of whether property is taken is directed more to what the owner retains and less to what he has lost .... But this rule only inspires the government to take property in slivers...."); see also Barros, supra note 4 , at $1869-72$ (1995); James S. Burling, Private Property Rights and the Environment After Palazzolo, 30 B.C. ENVT'L AfF. L. Rev. I, 50-64 (2002). To some extent Justice Rehnquist's dissent in Penn Central anticipated this approach, with his rejection of the balancing test in favor of viewing the regulation as imposing a servitude on the owner. For a critique, see Timothy J. Dowling, On History, Takings Jurisprudence, and Palazzolo: A Reply to James Burling, 30 B.C. Envt'L AfF. L. Rev. I, 65, 95-99 (2002).

68. Keystone Bituminous Coal Ass'n v. DeBenedictis, 480 U.S. 470, 500-02 (I987). In Keystone, a 
that "our takings jurisprudence forecloses reliance on such legalistic distinctions within a bundle of property rights."

Second, the new category would target changes in the law without any showing of overall effect on the property said to have been taken. Gauging changes in the law against the Takings Clause is nothing new. ${ }^{70}$ What the three Lingle categories have in common, however, is that they require some showing of the impact on the property owner of the changed legal situation. For Penn Central takings, the "economic impact of the regulation on the claimant," as well as the impact on the claimant's "investment-backed expectations," is an important part of the test. ${ }^{71}$ For Lucas, the key is the complete elimination of value..$^{2}$ Even for Loretto, what counts is the particular type of effect on the owner-physical displacement. ${ }^{73}$ In contrast, the test the Beach Renourishment plurality

coal mining company forced by a Pennsylvania statute to leave some of its coal in the ground to prevent subsidence argued that under Pennsylvania property law, the "support estate" was a separate property interest. $l d$. at $475-78$. All of the value of this estate, the company argued, had been taken. Id.

69. Id. at 500. One might argue that the plurality was merely following the lead of the Florida Supreme Court, which has made clear that it regards certain sticks in a beachfront property owner's bundle (for example, the right of access to the water) as separately protectable. See Walton Cnty. v. Stop the Beach Renourishment, Inc., 998 So. 2 d I I02, I I I (Fla. 2008). Of course, a state may extend takings protection under its own constitution more broadly than that under the federal constitution. But simply because a state regards a particular stick as distinct from the rest of the bundle, to date at least it has not followed that that stick would be separately protected under the Takings Clause. On the contrary, Pennsylvania law recognized the support estate as a separate estate, but that did not stop the Court from rejecting conceptual severance in Keystone in favor of a Penn Central analysis.

70. It happens all the time: A legislature or agency approves a new regulation that changes property owners' rights, and the property owners assert that the new regulation amounts to a taking. Indeed, even the classic physical invasion and occupation by the state amounts to a change in the law as applied to the property owner, for it signals that the state will not respect and enforce the property owner's rights to the parcel (or at least not the right to exclude).

71. Penn Cent. Transp. Co. v. New York City, 438 U.S. 104, I 24 (1978).

72. Lucas v. S. Carolina Coastal Council, 505 U.S. 1003, 1030 (1991).

73. Loretto v. Teleprompter Manhattan CATV Corp., 458 U.S. 4I9, 435-36 (1982). For a view that Beach Renourishment could be analogized to Loretto, see John R. Nolon \& Kristen M. Grzan, Rising Tides-Changing Title: Walton County v. Stop the Beach Renourishment, 38 Real Estate L.J. 392, 404 (2009). Equating physical occupation with the loss of an intangible right, however, is inconsistent with Lingle's admonition that regulatory takings involve government action "functionally equivalent to the classic taking in which government directly appropriates private property or ousts the owner from his domain." Lingle v. Chevron U.S.A., 544 U.S. 528, 539 (2005). Granted, at times the Court has expressed concern for one stick in the bundle - the right to exclude - in a way that might suggest that a state could never take it without compensation. Kaiser Aetna v. United States, 444 U.S. 164, I76, 179-80 (1979). In Kaiser, the Court called the right to exclude an "essential" stick in the bundle and found a taking. Id. But the Court still applied the Penn Central test, taking the deprivation of the right to exclude into account as a particularly important factor, to be sure, but still a factor in the evaluation of the overall impact. Id. at 178 .

Another example might be the right to inherit. Hodel v. Irving, 48I U.S. 704, 716 (1987) (involving a federal statute denying the right to inherit to highly fractionated ownership interests in individual allotments of Native American land); $i d$. ("[T]he regulation here amounts to virtually the abrogation of the right to pass on a certain type of property - the small undivided interest - to one's heirs. In one form or another, the right to pass on property - to one's family in particular-has been 
proposed disregards effect-or, what amounts to the same thing, defines the change in the law as the effect. The whole analysis of Florida law in the plurality opinion simply ignores the question of the economic impact on the property owners.

Third, there is no "override" in this new category as there was in Lucas, which held that even if there was a total deprivation of value, the government action still might not be a taking if it was justified by background principles of property law. ${ }^{74}$ Under the Beach Renourishment plurality, in contrast, if an established right is found to have been eliminated, that is the end of the inquiry. ${ }^{75}$ Whereas Justice Kennedy would grant the state courts some leeway to change the common law in light of changing social or technological factors,$^{76}$ the plurality provides no such defense. This omission accounts for the head-scratching quality of the claim before the Court-beachfront property owners complained that using public funds to restore the beach adjacent to their lots amounted to a taking. ${ }^{77}$

\section{c. The Impact of the New Category}

The new Beach Renourishment category would subsume all the other categories, and radically change takings law. The rewrite would start with Pennsylvania Coal. That case would end the same way, but with a radically different approach, one that would leave no room for consideration of the importance of the government's interests. The mining company would simply argue that it had an "established right" to mine the coal, pointing to the deed and to Pennsylvania's recognition of a separate "support estate" that it still owned. Then it would show that the statute had the effect of abolishing that right as to the mining company. It would not need to show that there was little public interest involved in its case, something Justice Holmes had taken pains to argue. Nor would it need to show that the right it lost was "very valuable." Neither plays any role in the Beach Renourishment test. ${ }^{78}$

part of the Anglo-American legal system since feudal times."). Here, too, the Court was careful to point out that for some holders of the fractionated interests, the value could be as much as $\$ 2,700$, which was not "trivial," and as to others it might cause the "escheat of potentially valuable timber and mineral interests." Id. at 714 .

74. Lucas, 505 U.S. at 1029 .

75. Stop the Beach Renourishment, Inc. v. Fla. Dep't of Envtl. Prot., I30 S. Ct. 2592, 2602 (2010).

76. Id. at 2616 (Kennedy, J., concurring in part and concurring in the judgment).

77. To be sure, the project would have an impact on them-there would be beach-goers behind their lots, maybe even hot dog vendors. See supra note 56, at 9-16. But these possibilities did not constitute the basis for their legal claim, and they would certainly fail under Penn Central, Lucas, or Loretto as a taking.

78. Similarly, the four dissenting conservative justices in Keystone would now prevail. The argument the takings claimant would make would somewhat track Chief Justice Rehnquist's dissent: "Operation of [the statute] extinguishes petitioners' interests in their support estates, making worthless what they purchased as a separate right under Pennsylvania law." Keystone Bituminous 
Andrus v. Allard ${ }^{79}$ would be in question now. In that case the Court rejected a takings challenge to a federal statute forbidding the sale of eagle feathers and other artifacts. ${ }^{80}$ The Court noted that the statute had caused the "destruction of one "strand' of the bundle" of property rights - the right to sell. ${ }^{81}$ But it left owners of the artifacts with the other strands ("the rights to possess and transport their property, and to donate or devise"), ${ }^{82}$ which had some value, though of uncertain amount. ${ }^{83}$ While this case involved a federal statute, the analysis would be the same: An established right - the right to sell the bird artifactswas eliminated by the federal statute. ${ }^{84}$

Finally, consider Pruneyard Shopping Center v. Robins, ${ }^{85}$ sometimes regarded as a precursor to judicial takings doctrine. The California Supreme Court had interpreted the California Constitution to protect free speech and petition rights in private shopping malls. ${ }^{86}$ In reaching that decision, it overruled an earlier opinion holding the opposite ${ }^{87} \mathrm{~A}$ mall owner asserted that it had suffered a taking. In rejecting the claim, Justice Rehnquist began by saying that "there has literally been a 'taking" of the right to exclude to the extent that the shopping center had lost the right to exclude the protesters. ${ }^{88}$ Under the Beach Renourishment approach, that would be the end of the matter: The right to exclude had previously been established (through the now overruled California Supreme Court opinion) and now was eliminated. Missing would be any need to go into the Penn Central factors that Justice Rehnquist found to support a finding that there had not been a taking. The impact on the mall and its value would be fairly restricted, and the mall was already open to the public, undermining any "reasonable investment-backed expectation" of an unlimited right to exclude. ${ }^{89}$

Coal Ass'n v. DeBenedictis, 480 U.S. 470, 520 (1987). We note, however, that the Beach Renourishment test goes even further than this. Chief Justice Rehnquist did, after all, include the following proviso: "[W]here the estate defined by state law is both severable and of value in its own right, it is appropriate to consider the effect of regulation on that particular property interest." Id. As we have pointed out, nothing in the Beach Renourishment test turns on the value of the right lost.

79. 444 U.S. 5I (1979).

80. Id. at $67-68$.

8I. Id. at 66 .

82. Id.

83. Id.

84. Id. at $67-68$.

85. 447 U.S. 74 (1980).

86. Id. at 78 .

87. See id.

88. Id. at 82 .

89. Id. at $82-83$. Pruneyard has been sharply criticized by property right advocates as unwarranted judicial activism. See, e.g., Stanley H. Friedelbaum, Private Property, Public Property: Shopping Centers and Expressive Freedom in the States, 62 ALB. L. REV. 229 (1999); Gregory C. Sisk, Returning to the Pruneyard: The Unconstitutionality of State-Sanctioned Trespass in the Name of Speech, 32 HARV. J.L. \& PUB. POL'Y 389 (2009). 
One need not review the Court's entire body of takings cases to appreciate the sweep of the Beach Renourishment test. It could be breathtaking. The plurality's test looks to a "right" established by state law. ${ }^{90}$ But what is a right? At one extreme, it could be the particular exercise of any general power that state law gives property owners. For example, while no state would ever eliminate "the right to exclude" as such, it might "eliminate" that right as to particular circumstances (as in Pruneyard). Using this approach in connection with the Beach Renourishment test would make it almost impossible for any state to enact new regulations. Anything a property owner could do before the regulation was enacted could be called a right, and then the right to do whatever was forbidden or lost under the new regulation would have been eliminated. ${ }^{\text {II }}$

Of course, takings law is notorious for its history of tests that seemingly presage significant restrictions on the regulation of property, but turn out to have little bite. If Beach Renourishment's surreptitious test were put into practice, might it turn out to be similarly limited? Perhaps it could be confined to cases where the loss of an established right inures to the benefit of the government or the public, rather than to another private individual. One can find a hint of this approach in the plurality opinion. In passing, it referred to a narrower standard by which only the elimination of an established private right in favor of public rights would be covered. ${ }^{92}$ This kind of distinction might save Pennsylvania Coal; Justice Holmes' opinion treats the regulation as essentially benefiting the private interest of the homeowner at the expense of another private entity, the mining company.

Perhaps it is the sheer vacuousness of this distinction in the context of the Takings Clause that accounts for the plurality's failure to give it more than a passing reference. We will eschew a lengthy (and dreary) exegesis of the impossibility of making the kind of sharp distinction between public and private that this limitation would require, and confine ourselves to two examples. Consider Pennsylvania Coal itself. Even Justice Holmes, who thought that "in ordinary private affairs the public interest does not warrant much" public interference, conceded,

90. Stop the Beach Renourishment, Inc. v. Fla. Dep't of Envtl. Prot., I30 S. Ct. 2592, 261 2 (2010).

91. See Tahoe-Sierra Pres. Council, Inc. v. Tahoe Reg. Planning Agency, 535 U.S. 302, 33 I (2002) (rejecting a claim that a thirty-two month moratorium on development constituted a total deprivation of value for that period); see also id. ("Of course, defining the property interest taken in terms of the very regulation being challenged is circular. With property so divided, every delay would become a total ban; the moratorium and the normal permit process alike would constitute categorical takings."). Justice Stevens went on to note that this "'conceptual severance' argument is unavailing because it ignores Penn Central's admonition that in regulatory takings cases we must focus on 'the parcel as a whole." Id. (quoting Penn Cent. Trans. Co. v. New York City, 438 U.S. I04, 130-3 I (1978)).

92. See Beach Renourishment, $130 \mathrm{~S}$. Ct. at 2601 ("States effect a taking if they recharacterize as public property what was previously private property."). 
"[n]o doubt there is a public interest" even in the "case of a single private house." ${ }^{\prime 93}$ And what are we to make of Pruneyard? Would that be the case of transferring a right (to exclude) from one private owner to other private parties (the protesters, in whose hands the right would be a right of entry)? Or would it be a case of eliminating the right to exclude, as to protesters, in order to benefit the public through the exercise of free speech rights? Obviously, it could be characterized either way. The difficulties are not just logical, moreover. Limiting the Beach Renourishment test to cases of "private to public" transfers is utterly inconsistent with the central holding of Kelo v. City of New London, ${ }^{94}$ which recognized that the transfer of private property from one private party to another could serve a public interest. ${ }^{95}$

In short, the plurality's approach employs a major sleight of hand. Distracted by the back and forth over the institutional question - can a state court commit a taking? - we may somehow fail to notice the major rewrite of takings law embodied in the proposed test. Granted, a major rewrite of takings law is not intrinsically bad. ${ }^{96}$ But smuggling it in $i s$.

\section{B. Feigned Obliviousness}

The plurality's sleight of hand is matched by its feigned obliviousness to a question the Court has made central to constitutional jurisprudence in the last decade and a half: federalism.

The text of the Fifth Amendment, the plurality argued, is written in the passive voice, and "is not addressed to the action of a specific branch or branches. ${ }^{\prime 97}$ There is something to be said for paying close attention to the text, in contrast to the general practice of courts and commentators (ourselves included) in applying a mythic "Takings Clause" that

93. Pa. Coal Co. v. Mahon, 260 U.S. 393, 413 (1922).

94. 545 U.S. 469 (2005).

95. Id. at $488-489$. Another potential limitation would be equally unavailing. Perhaps only rights that are severable are rights that can be "established" under state law for this purpose. If so, the impact of the Beach Renourishment test might be somewhat limited. There is nothing in the holding, however, to so suggest. In fact, even if the alleged rights of accretion and contact with the water existed, it is not clear whether they would be severable under Florida law. See Belvedere Dev. Corp. v. Dep't of Transp., 476 So. 2d 649, 652 (Fla.1985) (riparian rights not severable in condemnation context).

96. Whether Lingle can in fact provide the clarity so lacking in regulatory takings law remains to be seen (at least if it is not undermined so soon after its birth). Cf. Byrne, supra note 3, at 637 ("[Beach Renourishment] highlights deep and pervasive problems with the regulatory takings doctrine generally."). There is no shortage of proposals for fundamental rewrites of takings law, even after Lingle. The need for a major rewrite so soon after the Court's unanimous statement in Lingle is not, however, immediately apparent. Some good might come from serious attention to Lingle's stringent admonition that only state action functionally equivalent to the classic taking could amount to a regulatory taking.

97. Beach Renourishment, 130 S. Ct. at 2601. 
combines both the Fifth and Fourteenth Amendments. ${ }^{98}$ But in fact, the conclusions to be drawn from a textual analysis are quite unclear, as might be expected from the plurality's resort to "common sense" to support them. ${ }^{99}$ The Court has not consistently placed weight on the specification of institutional actors in other provisions. ${ }^{100}$

Here the plurality made a passing reference to federalism, arguing that it dictates that the Court not favor one branch of state government over another. State legislatures and executive bodies are subject to the Takings Clause, and state courts should be as well. ${ }^{\text {ror }}$ Why the Constitution treats state courts differently from other state agencies in the context of the Tenth Amendment, for example, was left unaddressed. ${ }^{102}$

This appeal to federalism was more Freudian slip than serious argument. In fact, the proposed new test is in serious tension with federalism in two ways not mentioned at all in the plurality opinion. One is its adoption of new federal oversight of an area previously left to the states; the other is an institutional tension with federalism implicit in the plurality's virtual elimination of state legislatures from any role in property definition.

\section{The Substantive Tension with Federalism}

For sixty years before United States $v$. Lopez, ${ }^{103}$ the Court largely left the question of the balance between federal and state power to the

98. Frank Michelman expresses this tendency well: "Clauses in the Fifth and Fourteenth Amendments command, in effect, that governments in this country shall pay for any property they may take from private owners. By settled usage, we call this constitutional command the Takings Clause." Frank I. Michelman, Property, Federalism, and Jurisprudence: A Comment on Lucas and Judicial Conservatism, 35 WM. \& MARY L. REv. 30I, 308 (1993). Not surprisingly, the conclusions to be drawn from a textual analysis do not necessarily accord with the plurality's. For example, two commentators closely analyzing the text and original intent conclude (through rather different analyses) that the whole doctrine of regulatory takings has a firm grounding when it comes to the states, but not the federal government. See Michael B. Rappaport, Originalism and Regulatory Takings: Why the Fifth Amendment May Not Protect Against Regulatory Takings, but the Fourteenth Amendment May, 45 SAN Diego L. Rev. 729, 758 (2008); Nicholas Quinn Rosenkranz, The Objects of the Constitution, 63 STAN. L. Rev. 1005, 1044-46, 1066-67 (2011).

99. Beach Renourishment, $130 \mathrm{~S}$. Ct. at 2601 .

Ioo. The Court has declined to limit the First Amendment to actions by Congress. See Mark P. Denbeaux, The First Word of the First Amendment, 80 Nw. U.L. Rev. I 156 (1986); Nicholas Quinn Rosenkranz, The Subjects of the Constitution, 62 Sran. L. REv. I209, I222 n.38 (2010). On the other hand, despite an earlier suggestion otherwise, see Bouie v. City of Columbia, 378 U.S. 347, 353-54 (1963), it ruled the Ex Post Facto Clause inapplicable to state courts, in part because the text is addressed to legislatures, see Rogers v. Tennessee, 532 U.S. 45I, 456-62 (2001).

101. Beach Renourishment, 130 S. Ct. at 2602.

102. The federal government can commandeer state courts (that is, require them to hear federal claims), but it cannot commandeer state legislatures or officials. See Printz v. United States, 52I U.S. 898 ( I 997 ) (officials); New York v. United States, 505 U.S. I44 (I992) (legislatures); Testa v. Katt, 330 U.S. 386 (1947) (courts).

103. 5 I4 U.S. 549 (I995). 
political process. ${ }^{104}$ In Lopez, the Court held a federal statute forbidding the possession of guns in school zones to be beyond Congress's Commerce Clause power. ${ }^{105}$ Five years later it struck down a provision of the Violence Against Women Act providing victims of domestic violence with a federal remedy, again on federalism grounds. ${ }^{106}$

One aspect of Lopez and subsequent cases has been the Court's adoption of an "economic activity" test under the Commerce Clause. If an activity is not an economic one, the Court will likely not uphold federal power over it, treating the aggregate effect of that activity as insubstantial. ${ }^{107} \mathrm{~A}$ second aspect-directly on point here-is that where an activity is one that states have traditionally handled, that fact will count heavily against federal power over it. What are these areas? In Lopez, the Court referred to "criminal law enforcement" and "education" as areas "where States historically have been sovereign."108 In Morrison, it referred to "family law and other areas of traditional state regulation."

This component of the Court's federalism jurisprudence raises an obvious problem for judicial takings. The definition and delineation of property rights have long been seen as state concerns. Indeed, the "brooding omnipresence" of the common law before Erie Railroad Co. $v$. Tompkins ${ }^{110}$ did not extend to property law. As Justice Rehnquist observed thirty-five years ago, "even when federal common law was in its

104. Even the major exception to this observation, Nat'l League of Cities v. Usery, 426 U.S. 833 (1976) (holding that the Tenth Amendment bars application of a federal labor wage and hour statute to state and local employees), was overruled within a decade. See Garcia v. San Antonio Metro. Transit Auth., 469 U.S. 528, 550 (1985) ("[T]he principal means chosen by the Framers to ensure the role of the States in the federal system lies in the structure of the Federal Government itself.").

105. Lopez, 5 I4 U.S. at $55 \mathrm{I}$.

Io6. United States v. Morrison, 529 U.S. 598, 618-19 (2000). The Court's "federalism revolution" has had its limits. In Gonzalez v. Raich, the Court upheld federal law criminalizing the home cultivation and consumption of marijuana. 545 U.S. I, 32-33 (2005). In United States v. Comstock, it upheld federal power to subject federal sex offenders to civil commitment after the date of their scheduled prison release. I30 S. Ct. 1949, 1965 (2010). These decisions do not, however, signal the end of the revolution. In both Raich and Comstock the Court was deeply split. In National Federation of Independent Business v. Sebelius, the Court upheld the individual mandate but declined to do so under the Commerce Clause, and also found that the way Congress had structured the Medicaid expansion violated federalism limits. I32 S. Ct. 2566, 2584-93 (2012) (Roberts, C.J.) (rejecting the Commerce Clause as a basis for the mandate); $i d$. at $2644^{-50}$ (Scalia, Kennedy, Thomas, Alito, JJ., dissenting) (same); id. at 2594 (Roberts, C.J.) (upholding the taxing power as the basis for the mandate); id. at 2666 (Scalia, Kennedy, Thomas, Alito, JJ., dissenting) ("Seven Members of the Court agree that the Medicaid Expansion, as enacted by Congress, is unconstitutional.").

107. See Morrison, 529 U.S. at 609-13.

108. Lopez, 514 U.S. at 564.

109. Morrison, 529 U.S. at 615.

I Io. 304 U.S. 64 (1938). See S. Pac. Co. v. Jensen, 244 U.S. 205, 222 (1917) (Holmes, J., dissenting) ("The common law is not a brooding omnipresence in the sky but the articulate voice of some sovereign or quasi-sovereign that can be identified...."). 
heyday under the teachings of Swift $v$. Tyson, ${ }^{\text {II }}$ an exception was carved out for the local law of real property."112

Of course, one can imagine some attempts to reconcile the two had the plurality seen fit to address the tension. Perhaps the concerns that have led the Court to constrain federal power when it comes to legislation simply do not apply to the Supreme Court because it is not a political body. In his concurrence in Lopez, for example, Justice Kennedy emphasized that if federal and state power overlapped too much, voters would not know whom to hold accountable. ${ }^{113}$ Courts are not expected to be politically accountable. A major problem with this distinction, though, is Beach Renourishment itself: The plurality scoffed at the argument that state courts should be treated differently from other state agencies, at least when it comes to the Takings Clause. Why should the Supreme Court be treated differently from Congress when it comes to federal intervention into areas previously left to states? ${ }^{\mathrm{II}}$

Perhaps federalism concerns are out of place in any individual rights case. This, too, is far from obvious. When the Court reinstated the death penalty in 1976 , it cited considerations of "federalism, as well as respect for the ability of a legislature to evaluate, in terms of its particular State, the moral consensus concerning the death penalty." ${ }^{115}$ And Kelo shows that federalism is highly relevant to the interpretation of the Takings Clause. ${ }^{116}$ The Court took pains to note that one factor in its refusal to adopt a narrow reading of the "public use" requirement of eminent domain was that adopting a broader reading would leave the states with flexibility to determine the scope of eminent domain. ${ }^{17}$

III. 4I U.S. I (1842).

I I2. Or. ex rel. State Land Bd. v. Corvallis Sand \& Gravel Co., 429 U.S. 363, 378-79 (I977) (Rehnquist, J.) (citation to Swift omitted); see id. at 378 ("The great body of law in this country which controls acquisition, transmission, and transfer of property, and defines the rights of its owners in relation to the state or to private parties, is found in the statutes and decisions of the state." (quoting Davies Warehouse Co. v. Bowles, 32 I U.S. I44, I55 (1944))).

I13. Lopez, $5^{14}$ U.S. at 576-77 (Kennedy, J., concurring).

I I4. It is not a sufficient answer to say that the federalism cases have concerned the Commerce Clause while Beach Renourishment concerned the Fifth and Fourteenth Amendments. Federalism concerns extend beyond the Commerce Clause. The Court has found them in the Tenth and Eleventh Amendments as well. Printz v. United States, 52 I U.S. 898 (1997) (Tenth Amendment); Seminole Tribe of Fla. v. Florida, 5 I 7 U.S. 44 (1996) (Eleventh Amendment); New York v. United States, 505 U.S. I 44 (I992) (Tenth Amendment).

I I5. Gregg v. Georgia, 428 U.S. I53, I86-87 (1976) (Stewart, Powell, Stevens, JJ.); id. at I76 (referring to the "deference we owe to the decisions of state legislatures under our federal system"); see Stanford v. Kentucky, 492 U.S. 361, 369-70 (1989) (citing Gregg for the relevance of federalism to the Eighth Amendment), overruled on other grounds by Roper v. Simmons, 543 U.S 55I (2005); see also Bond v. United States, I3I S. Ct. 2355, 2364 (20I I) ("Federalism also protects the liberty of all persons within a State ....").

I I6. Kelo v. City of New London, 545 U.S. 469, 489-90 (2005).

117. Id. 
To be sure, we do not argue that federalism necessarily precludes the creation of the new Beach Renourishment category. ${ }^{118}$ But we do insist that obliviousness-so pointed that it is hard to see it as inadvertent-is no way to deal with the issue. ${ }^{119}$

\section{The Institutional Tension with Federalism}

Commentators have noted the substantive tension with federalism, but they have overlooked a more subtle, yet equally important, tension. There is an institutional dimension to federalism. The Court has long taken the position that it is not for the federal government to decide how state governments should be structured or what powers each branch should have. ${ }^{120}$ Yet the clear import of the plurality's approach to parsing Florida law is to write state legislatures out of any participation in the definition and delineation of property rights. Not only has a new takings standard been smuggled in, but so has a major diminution of the role of state legislatures in the making of property law. Here, too, the plurality is seemingly oblivious to the federalism implications of its approach.

This hidden shift in power at the state level stems from the plurality's refusal to recognize that property law is a joint enterprise between state legislatures and courts, one in which common law and statutory law are thoroughly intertwined. The plurality's failure to recognize this is manifested in the way its version of Florida property law differs from the Florida Supreme Court's.

\section{a. Property Law Making as a Joint Enterprise Between State Courts and Legislatures}

One aspect of the joint enterprise is that state courts' supervision and management of the common law amount to a form of lawmaking, one that

II8. After all, respect for state authority is not an absolute constitutional value (as Raich shows). Perhaps federal intervention into the definition and delineation of property rights is justified even at some cost to federalism. We note, however, that it is largely the more conservative members of the Court-well represented in the Beach Renourishment plurality-who have most strongly endorsed the federalism limits on Congressional power.

I19. One might respond that we take the Court's expressions of concern for federalism too seriously. Cf. Frank B. Cross, Realism About Federalism, 74 N.Y.U. L. Rev. 1304, 1309 (1999) ("J]udges invoke the doctrine selectively to promote policy objectives."). This may be a sensible response for an academic, but not for the Court.

120. See Gregory v. Ashcroft, 50I U.S. 452, 460 (I99I) ("Through the structure of its government ... a State defines itself as a sovereign."); Highland Farms Dairy v. Agnew, 300 U.S. 608, 612 (1937) (rejecting a challenge to a Virginia statute on the ground that it unlawfully delegated legislative power to an executive agency: "How power shall be distributed by a state among its governmental organs is commonly, if not always, a question for the state itself."); see also Arizonans for Official English v. Arizona, 520 U.S. 43, 65 (1997) (finding no authority in Arizona law for initiative proponents to appeal a district court judgment); Morgan v. S. Bend Cmty. Sch. Corp., 797 F.2d 471, 477 (7th Cir. I986) ("[T]he Court has not held that Congress may decide who within a state's government has the authority to act on behalf of that government."). 
can be hard to distinguish from legislative lawmaking. There is nothing addressed by the common law that could not equally be addressed by statute. Courts and legislatures may differ on grounds of democratic accountability and expertise, but it is very hard to distinguish their actions in principle.

Take the well-known case of State v. Shack. ${ }^{121}$ The New Jersey Supreme Court held that property rights "serve human values. They are recognized to that end, and are limited by it." ${ }^{122}$ It concluded that a migrant farm owner could not exclude government-funded attorneys and medical workers seeking to assist migrant farm workers. ${ }^{123}$ Moreover, the court delineated the contours of the right of access, holding that reporters but not those selling goods had access, and recognizing the right of the farm owner to set reasonable conditions on entry (such as a requirement that anyone entering the farm provide identification) ${ }^{124}$ There is no reason, however, why these issues must be handled only by the courts. Other states have addressed the question through legislation that sets similar (though not identical) parameters to the right of access to migrant farms. Florida's statute governing access to migrant farms, for example, covers much of the same ground as State $v$. Shack, though its scope and content differ from Shack on some points. ${ }^{125}$

A second characteristic of this joint enterprise is that state lawmaking involves a good deal of interaction between courts and legislatures. Legislatures can overrule or modify common law decisions. ${ }^{126} \mathrm{~A}$ judicial decision is final in a particular case, but as to the general issues it decides, it is in fact never final, given this possibility. Many state legislatures (and governors) systematically monitor judicial decisions to determine whether a legislative response is needed. ${ }^{127}$ Moreover, much of the common law is determined in a legislative context, with courts taking legislative policy into account. While State $v$. Shack reads much like a common law opinion, in fact the task before the Court was to interpret the state trespass statute.

A third characteristic of the joint enterprise is that much of the interaction involves deference by courts to legislatures (or state constitutions). For example, in limiting the farm owner's right to exclude medical workers, lawyers, and others (or should we perhaps say, in "eliminating" the right to exclude them), State $v$. Shack did not treat the

I I. 277 A.2d 369 (N.J. 1971).

122. $I d$. at 372 .

I23. $I d$. at 374

124 ld.

125. See Fla. STAT, ANN. $\$ 381.008-.00897$ (201 1)

126. Judith S. Kaye, Things Judges Do: State Statutory Interpretation, 13 Touro L. Rev. 595, 602 (I997).

127. Shirley S. Abrahamson \& Robert L. Hughes, Shall We Dance? Steps for Legislators and Judges in Statutory Interpretation, 75 MINN. L. REv. I045, I054-59 (I991). 
common law in isolation. It discussed in some detail the report of the New Jersey Governor's task force on migrant farmworkers, as well as federal legislation, and put significant weight on the legislative policy of assisting migrant farmworkers, which an absolute right to exclude would defeat. ${ }^{12}$

This deference is typical in cases involving beach access. Consider the Oregon Supreme Court's handling of the public's right of access to beaches in State ex rel. Thornton v. Hay, decided in 1969-and which a quarter century later still provoked the ire of Justice Scalia. ${ }^{129}$ When a motel owner attempted to close the dry sand beach on its property to everyone but its guests, an Oregon trial court ruled that the public had acquired a prescriptive easement to use it. ${ }^{130}$ The Oregon Supreme Court affirmed but rested its holding instead on the English doctrine of custom. ${ }^{\text {I3I }}$ The court noted that "[s]trictly construed, prescription applies only to the specific tract of land before the court, and doubtful prescription cases could fill the courts for years with tract-by-tract litigation." ${ }^{32}$ Going over the doctrine of custom as laid out by Blackstone, which it found to be part of Oregon law, the court ruled that the "custom of the people of Oregon to use the dry-sand area of the beaches for public recreational purposes meets every one of Blackstone's requisites." "133

In reaching this result, the court took note of legislative policy. ${ }^{134}$ While it did not rest its decision on prescriptive easement grounds, it went out of its way to hold that such easements in favor of the public were in fact possible under Oregon law, referring to an Oregon statute that codified "a policy favoring the acquisition by prescription of public recreational easements in beach lands." "35 Among other things, that statute provided that it is in the public interest to do whatever is necessary to preserve and protect scenic and recreational use of Oregon's ocean shore. ${ }^{136}$ Interestingly, the court made clear that a statute of this sort could

128. Shack, 277 A.2d at 372-373.

129. 462 P.2d 671 (Ore. 1969). On Justice Scalia's views, see infra Part I.C.2.

130. As is common in other states, the mean high water line marked the divide between publicly and privately owned property on shore. The "wet sand" beach below the mean high water land was publicly owned; the "dry sand" beach - the area from the mean high water line landward to the point where vegetation could grow-was part of the beachfront owners' property. In practice, many beachgoers treated the entire beach, up to the vegetation line, as open to public use. Thornton, 462 P.2d at $673-75$.

131. Id. at 678 .

132. Id. at 676 .

133. Id. at 677 .

134. Id. at 674

I35. Id. at 676. (citing Or. Rev. STAT. \$390.610 (1994)).

I36. Or. Rev. Stat. $\$ 390.6$ IO(4) (I994). 
not, of course, "create public rights at the expense of a private landowner," ${ }^{\prime 37}$ it was quite relevant to the construction of the common law.

Courts in other states have shown similar deference to legislative policy in delineating the public trust doctrine. For example, in deciding that the public trust doctrine today protects public access not just for the older common law purposes of navigation and fishing, but also for recreational purposes, the New Jersey Supreme Court relied in part on a New Jersey statute that authorized the transfer of tidal properties to governmental bodies that maintained public parks fronting the beach, but only so long as the park remained open to the public. The court took the statute as evincing a legislative policy to encourage access to beaches. ${ }^{1{ }^{8}}$

In California, the Supreme Court faced the question whether certain privately owned shoreline properties in Santa Cruz had been dedicated to public use over the years. ${ }^{139}$ Among other things, the owners raised the objection to applying the state's rules on implied dedication to shorelines, since those rules had largely been developed in the context of roads. ${ }^{140}$ The court noted that there might be some basis for distinguishing the two contexts, ${ }^{14 \mathrm{I}}$ but still rejected it: "Even if we were reluctant to apply the rules of common-law dedication to open recreational areas, we must observe the strong policy expressed in the constitution and statutes of this state of encouraging public use of shoreline recreational areas."

137. Thornton, 462 P.2d at 676 .

138. Borough of Neptune City v. Borough of Avon-by-the-Sea, 294 A.2d 47, 54-55 (1972) (citing N.J. Stat. ANN. § I2:3-33, 34). The court has also recognized some (though not unlimited) power on the part of the legislature to authorize the grant of private rights in land covered by the public trust, notwithstanding the general common law notion that the state's interest in such lands could not be abdicated. Matthews v. Bay Head Improvement Ass'n, 47I A.2d 355, 360-62, 362 n.5 (N.J. I984).

The court also extended the doctrine to grant public access to the privately owned dry sand beach where "use of dry sand is essential or reasonably necessary for enjoyment of the ocean." Id. at $3^{6} 5$. Here, too, the court relied in part on the notion of common law changing to meet changing social needs, but also on the "statewide policy of encouraging... greater access to ocean beaches for recreational purposes"-a policy embodied in the state's Statewide Comprehensive Outdoor Recreation Plan. Id. at 364-65 (quoting Lusardi v. Curtis Point Prop. Owners Ass'n, 430 A.2d 881, 886 (I98I)).

139. Gion v. City of Santa Cruz, 465 P.2d 50, 52 (Cal. 1970).

140. See id. at 58 .

I4I. Id. ("This emphasis on roadways arises from the ease with which one can define a road, the frequent need for roadways through private property, and perhaps also the relative frequency with which express dedications of roadways are made.").

142. Id.; see id. at 59 (citing the Constitution and a variety of "legislative enactments that indicate the strong public policy in favor of according public access to the coast"). For another useful discussion of state courts' approach to public policy in determining public access to private property, see Kate Shelby, Taking Public Interests in Private Property Seriously: How the Supreme Court ShortChanges Public Property Rights in Regulatory Takings Cases, 24 J. LAND UsE \& ENVTL. L. 45, 53-58 (2008). 
Granted, state judicial deference to legislatures is far from absolute. State courts sometimes suggest, for example, that there are limits to state legislatures' power to regulate in areas covered by the public trust doctrine ${ }^{143}$ Citing constitutional grants of judicial power, they may resist state legislative initiatives in areas long dominated by the common law, as with tort reform. ${ }^{144}$ In addition, a state court may invite legislatures to reconsider a judicial decision or revise existing statutes; ${ }^{145}$ it may even "choose a particular solution in the hope of fostering legislative action." $" 146$

Moreover, legislatures sometimes show deference to state courts. In formulating statutes they often take the common law into account. ${ }^{147}$ For example, in the Beach and Shore Preservation Act, the Florida legislature was careful to make the general proclamation that "there is no intention on the part of the state to extend its claims to lands not already held by it or to deprive any upland or submerged land owner of the legitimate and constitutional use and enjoyment of his or her property." ${ }^{148}$ It went on to say that if a project could not be accomplished consistent with that aim, the state should use its eminent domain power. ${ }^{149}$

Still, while deference and influence can work both ways, there is no doubt that judicial deference to legislative policy plays a particularly important role. It helps answer the charge that state courts' lawmaking power (through change in the common law) is undemocratic, given that courts are not accountable to the electorate.

\section{b. Dueling Versions of Florida Property Law}

The Florida Supreme Court's handling of the property issues before it fits quite comfortably with our description of state lawmaking, including a degree of deference to the legislature. As noted earlier, the court found that private beachfront owners' rights to future accretion was merely a "contingent right," not a protectable property right..$^{150}$ This

143. E.g., Neptune City, 294 A.2d at 5I-55.

144. See, e.g., Adrian Vermeule, The Judicial Power in the State (and Federal) Courts, 2000 Sup. CT. Rev. 357 (2000).

145. Abrahamson \& Hughes, supra note I 27, at 1054-59; Kaye, supra note 126, at 603 .

146. Abrahamson \& Hughes, supra note 127 , at 1056 .

147. See Kaye, supra note 126 , at 601 .

148. FL. STAT. § I6I.I4I (20I2) ("Property rights of state and private upland owners in beach restoration project areas.").

149. Id. The solicitude for property rights is not surprising, coming from a legislature that enacted a general statute that provides, as a matter of state law, for compensation in case of regulatory takings, Bert J. Harris, Jr., Private Property Protection Act, Fla. StaT. § 70.00I (2010), and which received an "A" from a prominent property rights group formed to promote state legislative restrictions on eminent domain after the Kelo decision. See Marc Mihaly \& Turner Smith, Kelo's Trail: A Survey of State and Federal Legislative and Judicial Activity Five Years Later, 38 EcoLOGY L.Q. 703, 709 (20I I).

150. Walton Cnty. v. Stop the Beach Renourishment, Inc., 998 So. 2d I 102, I I 8 (Fla. 2008). 
right, the court said, "arises from a rule of convenience intended to balance public and private interests." 151 In finding that the reasons for recognizing the contingent right did not apply in the context of restoration of critically eroded beaches, the court took careful note of the balance the legislature had struck between public and private interests. ${ }^{152}$ In particular, the court considered that restorations under the Florida statute would remove "the upland owner's ... risk of losses and repairs due to erosion" as well as the prospect of future accretions. ${ }^{153}$

Similarly, the Florida Supreme Court found that there was no property right to contact with the water; any such right was merely ancillary to the right of access to the water. Here, too, the court essentially deferred to the legislature's determination that beachfront property owners' access to the ocean would be adequately protected in the restoration projects. ${ }^{154}$ Throughout its opinion, the majority expressed respect for the choices made by the legislature as it sought to balance its responsibility under the Florida constitution to protect the beaches and to respect private property. ${ }^{\mathrm{ISS}}$ For the dissent, this deference simply revealed "the majority's desire to destroy protected private-property rights" in an effort to uphold the statute. ${ }^{156}$

Of course, the Florida Supreme Court did not focus solely on legislative policy. Much of its discussion of the basic framework of beachfront property rights consisted of a look at prior Florida cases. It is clear, however, that even in so doing it was to some extent taking legislative policy into account, given that in enacting the Florida Beach Restoration statute the legislature expressly affirmed its intention to respect the common law of property. The idea of a sharp distinction between common law and statutory law makes no sense in this context.

A sharp distinction is, however, exactly what the Beach Renourishment plurality drew in its analysis of Florida law. It treated the relevant law 'as consisting entirely of judicial opinions in Florida. The plurality began by noting the petitioners' claims that their rights to accretion and contact with the water had been eliminated. The plurality responded that such claims could be upheld only if the petitioners could meet the burden of showing that such rights were established-a showing

151. $I d$. at I I 18 .

152. Id. at I I 18-19.

153. Id. at I I 18 .

154. Id. at II 19-20. The court's deference was not total. It warned that if in the course of beach restoration the state made the beach so wide as to "materially and substantially impair the upland owner's access," that would amount to a taking. $I d$. at i i 20 n. I6.

I55. See, e.g., Walton Cnty., 998 So. $2 \mathrm{~d}$ at 1107 (condoning the legislature's attentiveness to "the importance and volatility of Florida's beaches"); id. at II I5 (applauding the legislature's attempt to draft the Act to keep "a careful balance between the interests of the public and the interests of the private upland owners").

I56. Id. at I 127 (Lewis, J., dissenting). 
that would have to be made in the face of what the plurality claimed was deference to the Florida courts in case of doubt. ${ }^{157}$ In the course of a detailed discussion of Florida law, the plurality made no mention whatsoever of what the Florida Supreme Court had treated as significant - the state constitutional mandate to protect the beaches and the legislature's view that beachfront property owners' access to the ocean would not be unduly interfered with by the renourishment projects. Its sole focus was on Florida case law.

The version of Florida law the plurality analyzes is a desiccated one, taking no account of statutes or the announced policy of the state's political branches. But writing state legislatures out of the picture has its uses. Under the plurality's new takings category, only judicial opinions would count in determining whether an established right had been eliminated. ${ }^{158}$

In one sense, of course, the plurality's approach would not disempower state legislatures. The same interactive process of lawmaking could continue. When the federal courts assessed the making of state property law against the strictures of the Takings Clause, however, the legislature's input would count for nothing. Conceivably a case could be made for such an outcome. ${ }^{159}$ But the case ought to be made, and its tension with the Court's federalism project acknowledged.

The utter neglect of any real consideration of federalismsubstantively and institutionally-is, sadly, not unprecedented. In Bush v. Gore $^{160}$ the Court simply ignored the obvious issues of standing and political question, notwithstanding its pious assertions in other contexts of the need for careful attention to the modesty of the Court's role. The Court promised that Bush v. Gore would be unique. ${ }^{161}$ Apparently, the plurality took that promise to be confined to the Court's substantive

I57. Despite the plurality's claim to give deference to state courts in determining whether a right was established, it essentially reviewed Florida judicial opinions de novo, developing its own framework for analyzing the issues and reaching its conclusions essentially independently of the Florida Supreme Court's approach.

158. The hostility to the input of state legislatures is strongly reminiscent of Lucas. In that case, the Court held that a complete deprivation of economic value constituted a taking, unless the regulation could be justified under "background principles" of state law. Lucas v. S. Carolina Coastal Council, 505 U.S. 1003 , I006-3I (1992). The opinion, written by Justice Scalia, was clear that these background principles were the sole province of the state courts. Id. Dissenting, Justice Stevens noted that the majority's unwillingness to allow legislative input into the "background principles" of state common law that might justify a complete deprivation of value "den[ied] the legislature much of its traditional power to revise the law governing the rights and uses of property." Id. at Io68-69 (Stevens, J., dissenting).

159. Some commentators, for example, worry that state legislatures are too easily captured by interests hostile to the protection of property rights. See, e.g., Dennis J. Coyle, Takings Jurisprudence and the Political Cultures of American Politics, 42 CATH. U. L. Rev. 817, 853-54 (1993).

I60. 53 I U.S. 98 (2000).

161. Id. at 109 ("Our consideration is limited to the present circumstances, for the problem of equal protection in election processes generally presents many complexities."). 
holding regarding equal protection and not to the practice of blatantly ignoring whole bodies of relevant case law.

\section{Knowing Artlessness}

Having established a test that ignores the Court's federalism holdings and substitutes a desiccated version of state property law for the real thing, the plurality next undertook a close analysis of Florida law on accretion and avulsion to see whether any established right had been eliminated. The plurality's analysis betrays a seemingly artless conception of property rights, epitomized by its resort to a deus ex machina-a Florida case never cited by the Florida Supreme Court that, miraculously, resolves the entire question. This kind of exercise is appropriate for a "Where's Waldo" adventure, but takings law deserves better.

\section{The Plurality's Conception of Property Rights}

At the core of the plurality's approach lies this view: Property owners must sometimes suffer the effects of uncompensated changes of regulations-regulatory takings law is no guarantee of stasis-but the underlying definitions of what constitutes property will remain stable over time (at least once they are established). This view is implicit in the plurality's position that any elimination of an established property right would occasion a requirement of compensation. ${ }^{\text {I62 }}$

This view, however, betrays a fundamental misunderstanding of how property law typically works. There is no such thing in property law as an "established property right" plain and simple. The "established" quality of any property right is always provisional and relative. In turn, that means that the judgment whether a right has been "eliminated" can never be as straightforward as the plurality's test implies. Any time a federal court answers the question whether an established right was eliminated, it will of necessity engage in an act of judgment-or rather, of second-guessing states' judgments-about how property should be regulated. ${ }^{163}$

I62. Such a view accords with the most conservative conception of property law, which sees it as essentially static and unchanging, with only a highly constrained potential for occasional change. See Richard A. Epstein, The Static Conception of the Common Law, 9 J. Legal Stud. 253, 258 (1980) ("The rules with respect to real property and its unauthorized entry are very old, and they are very constant."); id. at 265-69; Richard A. Epstein, Taking Stock of Takings: An Author's Retrospective, I5 WM. \& MARY BILL RTS. J. 407, 413-14 (2006). Even in Lucas, which held that complete deprivation of value could amount to a taking, the Court provided that the state regulation might be justified on the basis of "background principles," which as Justice Kennedy took pains to note, might change over time. Lucas, 505 U.S. at 1035 (Kennedy, J., concurring). In Beach Renourishment, the plurality set out no comparable exception to its proposed rule that elimination of an established property right violates the Takings Clause.

I63. For other discussions, see Byrne, supra note 3, at 629 ("Placing property 'rights' at the center 
There are two reasons for this ambiguity. The first is that property rights are relative to a purpose; in fact, defining property rights and regulating them are essentially the same activity. The second is that courts routinely expect rights holders to weigh property rights differently, depending on the context.

\section{a. Rights and Purposes}

Property rights can be established in state law for one purpose but not another. Consequently, rejecting the idea of a property interest in something does not necessarily constitute taking away an established right, even when a property interest in that same thing was recognized earlier. This is especially so with regard to particular sticks in the property bundle - the implicit focus of the plurality's test.

Consider one typical sequence of state cases. In I94I the Florida Supreme Court stated in Dunahoo v. Bess that a widower had a "property right" in his wife's corpse. ${ }^{164}$ Did this mean that Florida residents now had an established property right in their deceased spouse's corpse? If it did, then subsequent cases could be understood as chipping away at the right, taking it away entirely, and then giving it back.

In 1950, in Kirksey v. Jernigan, the Florida Supreme Court "clarified" Dunahoo (as the court itself characterized its action years later) as recognizing the "right to the possession of the body of a deceased person for the purpose of burial, sepulture or other lawful disposition." "65 this an "elimination" of an established right? A clarification?

Then in I986, in State v. Powell, the court rejected a claim that a Florida statute committed a taking of property by permitting a medical examiner to remove a decedent's cornea for transplant without the express permission of the kin. ${ }^{166}$ The "universally accepted" view, the court said, was that "the next of kin has no property right but merely a

of regulatory takings analysis requires scholastic distinctions between sticks and bundles and invites ideological manipulation behind a mystifying shield."); Laura S. Underkuffler, Judicial Takings: $A$ Medley of Misconceptions, 6I SYRACUSE L. REV. 203, 2I I (201 I) ("The idea of a judicial taking assumes that a 'previously established' or vested right existed in law, and was destroyed by the court's later decision. However, courts do not 'make' the law, or fabricate it from whole cloth; they interpret the common law, or interpret statutes, or interpret rules and regulations. We assume that courts are competent, and are aware of what they do. If a prior interpretation of the law by a court was later repudiated by that court, it is because the court believed that was wrong; and it is theoretically impossible for a party to claim a protected right in a previously erroneous interpretation.").

I64. 200 So. 54I, 542 (I $94 \mathrm{I}$ ) (claim for damages from careless embalming of deceased wife's body).

I65. 45 So. $2 \mathrm{~d}$ 188, 189 (1950) (claim for damages relating to undertaker's having embalmed plaintiff's deceased child without authorization). See State v. Powell, 497 So. 2d II 88, I I9I (Fla. 1986) (explaining that Kirksey "clarified" the right expressed in Dunahoo).

I66. Powell, 497 So. $2 \mathrm{~d}$ at II92. The statute forbade removal of the corneas if the next of kin objected, but required no notice to them of their right to object. Id. at I I89. 
limited right to possess the body for burial purposes." ${ }^{167}$ If Kirksey was a "clarification," the reference in Powell to the next of kin having "no" property right might well sound like an elimination of a right.

In 200I, in Crocker v. Pleasant ${ }^{168}$ the court again faced the issue and ruled that parents did have a "protectable property interest" for purposes of a $\S 1983$ claim $^{169}$ against a police department whose alleged negligence caused their son's body to be buried without their knowledge.$^{170}$ This time it clarified the broad "no property" language of Powell, noting that Powell was decided in light of a shortage of transplantable corneas. At least for the purposes of Fourteenth Amendment protection, the next of kin had a "quasi-property interest" in the body. ${ }^{171}$ Whether a "quasi-property" interest amounts to an established right is an interesting question.

There is certainly nothing unusual about this sequence of a broad statement subsequently clarified in both narrowing and expanding ways. But the potential for a claim that a property right was "established" at one point and later "eliminated" is obvious. Indeed, one impact the adoption of a new Lingle category might have is that state courts might think twice before narrowing earlier, rather broad declarations of property rights (as happened in Kirksey and Powell), out of concern that they would be held to have committed a taking. Or they might be hesitant to broaden them (as arguably happened in Crocker) out of concern that any subsequent narrowing of the right in other circumstances would amount to a taking.

What accounts for this kind of sequence, which is hardly unusual? At base, it reflects the fact that there is no real difference between defining or delineating property rights, on the one hand, and regulating them, on the other. It is easy to think of them as conceptually and institutionally distinct: Property rights are what you have, whereas regulations are things legislatures and agencies do to people who have them. But rather than characterizing the sequence of cases from Dunahoo to Crocker as potentially establishing and eliminating rights, we could just as accurately describe what the Florida Supreme Court was doing as regulating the relations among private parties with respect to a corpse, as well as setting out the powers of the state vis-à-vis private parties with respect to a corpse.

I67. Id. at I I92.

I68. 778 So. $2 \mathrm{~d} 978$ (Fla. 200I).

I69. 42 U.S.C. \& I 983 (2006).

170. Crocker, 778 So. $2 \mathrm{~d}$ at 984 .

I7I. See id. at 985 ; see also id. at 988 (describing a property interest in body as a "legitimate claim of entitlement"). 


\section{b. Rights and Context}

Courts routinely expect rights holders to evaluate how solid (or vested) their rights are. Consider Kendall v. Ernest Pestana, Inc. ${ }^{172}$ The California Supreme Court rejected the rule, in force then in most states, that a clause in a lease requiring the landlord's consent to assignment or sublease gave the landlord power to reject a proposed transfer for any reason. Instead, the court held, the landlord's rejection of a proposed transfer by the tenant must be commercially reasonable. In confronting the claim that landlords had reasonably relied on the prior rule, ${ }^{173}$ the court in effect had to ask whether the landlord's right to absolute discretion was an "established" one.

In answering "no," the California Supreme Court made several points. One was that while the question had been addressed by lower courts, it had never decided the question itself. A right affirmed only by lower courts is not the same as one blessed by the state's highest court. Another factor was that the trend in other states was toward the minority rule requiring landlords to show commercial reasonableness. ${ }^{174}$

There was nothing unusual about the approach the court took. But if the California court were to apply the test put forth by the Beach Renourishment plurality-whether a court has "eliminated" an "established" right - there could only be confusion. Certainly landlords would feel like they lost something after Kendall - the right to refuse a proposed sublease without having to justify the decision to a court. But perhaps the trend elsewhere showed that the landlord's right was never fully established in the first place. Or perhaps the trend in other states eroded - partially eliminated - the established rule. If the latter, perhaps California did not eliminate an established rule; other states did. Indeed, one of the features of courts' expectation that property rights holders will pay attention to trends in other states is that rights may gradually recede without any one particular state being responsible for that recession. ${ }^{175}$

172. 709 P.2d 837 (Cal. 1985).

173. The argument was that landlords had been agreeing to lease provisions stating merely that their consent was required, without adding that it could be withheld for any reason, because thenexisting law so provided. $I d$. at $840-4 \mathrm{I}$.

174. Id. at $84 \mathrm{I}-42$.

175. These points hardly exhaust the potential inadequacies of the plurality's either/or approach to establishment and elimination. For example, a right can be "established" without anyone knowing it. One form of property scholarship is to identify from a range of cases the existence of a right that must undergird their holdings, even if no court has previously recognized the right as such. The "reliance interest in property" may be one such example. See Joseph William Singer, The Reliance Interest in Property, 4o Stan. L. Rev. 6I I, 745 (1988). For other examples, see Joseph William Singer, The AntiApartheid Principle in American Property Law, I ALA. C.R. \& C.L. L. REv. 91 , 92 (20I I); Lior Jacob Strahilevitz, The Right to Destroy, II4 YALE L.J. 781, 783-84, 787-9I (2005). The template of these "rights discoveries" is the identification of a pattern of regulation (by statute or common law or both), the express labeling of which as a right is thought to help analysis of other related questions about the proper scope and content of the regulation. If a number of state courts, examining the pattern, 
The fluidity evident in Kendall is not just a matter of private law rights. Courts may well define something as a property right for certain private law purposes but not for takings purposes. Or they may define them as rights for procedural due process purposes but not for takings purposes. ${ }^{17^{6}}$ Similarly, something may be property for Fourth Amendment purposes but not takings purposes.

Alaska's regulation of salmon fisheries provides a good example. Commercial salmon fishers must have permits to harvest Pacific salmon in Alaskan waters. Between 1996 and 2002, the state issued regulations shortening the fishing season and imposing other restrictions that reduced commercial salmon fishers' harvest. ${ }^{17}$ Permit holders challenged the regulation as a taking of their permits. The Alaska Supreme Court ruled that the permits did not constitute property under state law and rejected the takings challenges. ${ }^{178}$

What is striking is that in the course of its opinion the court acknowledged that it had previously held that the permits do constitute "“ordinary personal property' for inheritance purposes," "subject to execution for past due child support claims." ${ }^{80}$ It also took note of its earlier holding that permit seekers have a property interest in the permit for purposes of the notice and hearing requirements of the due process clause. ${ }^{181}$ In rejecting the takings claim, the court made clear that in no way did it intend to cast doubt on these earlier holdings. The permits are not "property interests for the purposes of takings claims."

These distinctions make good sense. A certain interest might be important enough to merit procedural protections before its deprivation; that interest could be recognized as property for purposes of the due

conclude that there is a right to destroy, for example, what are we to say of a state court that, upon examining the same trend in its own law, declines to recognize a right to destroy? Whether we say the right was never established in that state, or the right was eliminated by that court decision, amounts to a matter of characterization, not substance.

I76. See Hoffman v. City of Warwick, 909 F.2d 608, 620 n.I I (Ist Cir. I990) ("Our holding that plaintiffs have not been deprived of a property interest for Takings Clause purposes is not determinative of the issue whether they had a property interest for procedural due process purposes.").

177. Vanek v. Board of Fisheries, 193 P.3d 283, 285-87 (Alaska 2008).

178. It rested this conclusion in part on the fact that the statute providing for the permits specifically stated that they constituted "a use privilege that may be modified or revoked by the legislature without compensation," id. at 288-89 (quoting ALASKA STAT. $\$ 16.43 .150(e)$ ), and in part on the fact that the Alaska Constitution forbids the creation of an "exclusive right or special privilege of fishery," id. at 290 (quoting AlASKa CONST. art. VIII, \& 15). In other words, consistent with our earlier discussion, see supra Part I.B.2.a, the court relied heavily on legislative (and state constitutional) sources in deciding whether there was a property right in the permits.

I79. Vanek, 193 P.3d at 29I (quoting Wik v. Wik, 681 P.2d 336, 337 (Alaska I984)).

180. Id. (quoting Anderson v. Anderson, 736 P.2d 320, 324 (Alaska 1987)).

I81. Id. (citing Miner's Estate v. Commercial Fisheries Entry Comm'n, 635 P.2d 827, 832 (Alaska I98I)).

182. Id. at 292. 
process clause. There is no obvious reason, however, why according some degree of procedural protection before depriving someone of an interest necessarily entails a requirement of compensation if that interest is taken away or terminated after a hearing-or if any recognition of the interest is withdrawn entirely as a matter of defining property rights. Indeed, to hold otherwise might ultimately result in less protection. Courts might hesitate to accord procedural due process safeguards to particular interests lest the state now find that the state-imposed withdrawal or termination of those interests required compensation.

While there is a great deal to be said for it, the idea of "property rights for some state law purposes but not takings purposes" does not fit within the Beach Renourishment plurality's simple sequence of a takings claim proven when a right is first "established" and then "eliminated." If a property interest was earlier recognized in the permit, why would the Alaska court's denial of any property interest under the Takings Clause not itself constitute a taking under the proposed new category?

Of course, the fact that the plurality would bring an end to this kind of nuanced view of property rights does not, in itself, show that the plurality was wrong. Perhaps there is too much danger of manipulation. In theory, a state court could evade the Takings Clause entirely by a simple maneuver: holding all its state-created property interests to be property for state law purposes but not takings purposes. ${ }^{18_{3}}$

There is a well-established means of dealing with any state manipulation of its property law to avoid a constitutional compensation requirement. In general, a federal court's deference to a state court's construction of state law is subject to a "fair and substantial basis" or "fair support" test. ${ }^{184}$ The plurality was plainly not interested in a test aimed at preventing state court evasion of federal law through manipulation of state law. ${ }^{185}$ It seems preferable, however, to deal with the possibility of evasion or manipulation by a test designed to counter

I83. An unlikely maneuver of this sort would, however, likely fall afoul of the Court's rejection of the notion that a state could define all property rights as being subject to a condition that they may be eliminated without compensation. Under Palazzolo v. Rhode Island, 533 U.S. 606 (2001), the state cannot even automatically hold property owners to the law in place at the time property was acquired. See id. at 626 ("This Court rejects the ... rule that a purchaser or a successive title holder ... is deemed to have notice of an earlier-enacted restriction and is barred from claiming that it effects a taking."); id. at 627 ("The State may not put so potent a Hobbesian stick into the Lockean bundle.").

184. Stop the Beach Renourishment, Inc. v. Fla. Dep't of Envtl. Prot., I30 S. Ct. 2592, 2608 (2010). See, e.g., Wolfe v. North Carolina, 364 U.S. 177,185 (1960) ("It is settled that a state court may not avoid deciding federal questions and thus defeat the jurisdiction of this Court by putting forward nonfederal grounds of decision which are without any fair or substantial support."); Ward v. Love County, 253 U.S. I7, 22-23 (1920) (holding that state court judgments based on independent state law grounds are beyond Supreme Court review unless the state law grounds are "plainly untenable."). For a useful overview, see Laura S. Fitzgerald, Suspecting the States: Supreme Court Review of State-Law Judgments, 101 Mich. L. REv. 80 (2002).

185. Beach Renourishment, 130 S. Ct. at 2608. 
evasion. ${ }^{186}$ Eliminating the possibility of limited recognition of particular property rights - recognition that does not extend to takings protectionwould make courts and legislatures hesitate unduly before granting any protective status to interests.

In short, the fundamental importance of context to property rights renders the plurality's simplistic approach - "a right is established or eliminated"- unworkable. Any attempt to implement the new category proposed by the plurality will have to deal with this feature of property law, one the plurality entirely overlooked. Property rights-especially particular sticks in the bundle-are often not "established" in the on/off sense in which the plurality conceived them. And even a right that did appear more established in that sense when it comes to relations among private parties might still not be established for purposes of the Takings Clause.

\section{Justice Scalia's Guest Turn as a Florida Justice}

The artlessness built into the plurality's proposed test was most on display in Justice Scalia's would-be virtuoso performance as a state judge, outdoing the Florida Supreme Court in the analysis of Florida case law. The plurality was quick to cast aside the Florida Supreme Court's framework, implying that it had asked the wrong questions. ${ }^{187}$

The divergence relates to the key question. Because the statute governing the program provided that the boundary between public and private would be permanently fixed at the mean high water line over the last two decades or so, property owners would lose the possibility of gaining land through future accretion, and they would also lose direct contact with the water. Both points were undisputed.

To reach its conclusion that the loss of accretion and contact with the water did not constitute a taking, the Florida Supreme Court focused on the prior hurricanes as avulsive events. As it noted, Florida law had long provided that, whereas slow and gradual changes (accretion and erosion) move the boundary line, a sudden change wrought by a hurricane does not; the property line is fixed at the mean high water line before the hurricane ${ }^{188}$ In a case where beach renourishment might be undertaken, an avulsive event - a hurricane-would already have taken place, fixing the boundary line. In turn, that would mean that the beach restoration statute, which provided that the boundary line would be at

I86. See E. Brantley Webb, How to Review State Court Determinations of State Law Antecedent to Federal Rights, I20 YALE L.J. I192, 1219-24 (2011).

I87. See Beach Renourishment, $130 \mathrm{~S}$. Ct. at 260 I n.5 ("We ... need not resolve whether the right of accretion is an easement, as petitioner claims, or as Florida claims, a contingent future interest.").

I88. Walton County v. Stop the Beach Renourishment, Inc., 998 So. 2d IIO2, III7 ("[I]f the shoreline is lost due to an avulsive event, the public has the right to restore its shoreline up to th[e] MHWL [mean high water line]."). 
the mean high water line over the last two decades, had merely formalized a fixing of the property line that had already taken place through the hurricanes. This alone would be sufficient to deny the claim that the statute had taken anything that Florida law guaranteed the property owners. This conclusion, the Florida Supreme Court found, impinged on no rights; the alleged right of accretion was contingent, not vested, and the alleged right of contact was incidental to other rights (primarily access to the water) which the beach restoration did not affect.

The Beach Renourishment plurality analyzed the question in an entirely different way. For the plurality, the question was whether there was an "exception" to one of two core principles of Florida law, both identified by the plurality. The core principles were the state's right to replenish the portion of the beach it owned, and its continued ownership of formerly submerged land after it was newly exposed by avulsion, even if the result was to interrupt "the littoral owner's contact with the water." ${ }^{\text {"189 }}$ The question, according to the Court, was whether the state could take advantage of the second principle if it was the cause of the avulsion-or whether that circumstance was an exception to the state's right to replenish or fill its own property. By this reckoning, it became crucial to find a prior case that showed definitively that there was no such exception. ${ }^{190}$

The plurality then proceeded to find that there was indeed such a case-Martin v. Busch, ${ }^{191}$ decided in 1927-which neither the majority nor the dissent in the Florida Supreme Court had cited. In effect, the plurality determined that all seven members of the Florida Supreme Court had somehow overlooked a key case. Martin, the plurality asserted, shows that even when the state causes an avulsion, it owns the land thereby created-even if beachfront owners' contact with the water is interrupted. The plurality's loudly proclaimed "deference" to state courts in determining whether a right was established ${ }^{192}$ is thus something of a smokescreen. What truly stands out is the image of the U.S. Supreme Court besting the Florida Supreme Court in appreciating the significance of the crucial Florida case.

There is one problem with this dazzling performance: It ignores the judgment of the Florida Supreme Court that Martin was entirely unnecessary to the decision - a judgment that does not appear to have rested in ignorance of the existence of the case. In Martin, the Florida Supreme Court faced the question of who owned land that was exposed

189. Beach Renourishment, 130 S. Ct. at 261 I.

190. Id. The plurality treated the two core principles as "background principles" under Lucas. See id. at 26I2 (citing Martin v. Busch, I 22 So. 274 (Fla. 1927)). This strongly suggests that the plurality sees it as the role of the Supreme Court to determine what those background principles are.

191. I I2 So. 274 (Fla. 1927).

I92. Beach Renourishment, I30 S. Ct. at 2608 n.9. 
when the state partially drained Lake Okeechobee: the state, which owned the lake and lakebed, or the private property owners fronting it? Martin held in favor of the state. ${ }^{193}$

It is easy to see how tempting it might be to treat Martin as the case that saved the Florida Supreme Court from being labeled the first "judicial taker." One can (as the plurality did) analogize the state's draining of the lake to the state's dumping of sand along the shoreline. Both can be seen as artificial avulsions-sudden changes in the shoreline caused by state actions. Since Martin held that the newly exposed land continued to belong to the state-as it had while it was underwater-the holding must have rested on the principle that an artificial avulsion fixes the property line just as natural one does. This may have been "odd" and "counter-intuitive," 194 but it was Florida law, even if the Florida Supreme Court had somehow failed to realize it.

There is, however, a major problem with this scenario: Martin itself said nothing about avulsion, let alone artificial avulsion, nor did it discuss the alleged right of contact. It did not even use the word. Rather, it declined to apply the general principle of accretion to award title to the landowners.

Nor is this just a question of labeling. Why not give title to the landowners? Prying a definitive answer out of Martin is not easy, if it is possible at all. ${ }^{195}$ At times the opinion reads as if the court's conclusion rests on the proposition that the particular deeds the property owners held simply did not cover more than the land they initially held, whatever the general principles of riparian law might be. ${ }^{196}$ There are also indications that the court's view rested in part on its understanding of the title Florida received to the land in question under a federal statute. ${ }^{197}$ Still, the court does end its opinion with a general discussion of some principles of riparian law. ${ }^{198}$

One explanation might relate to the potentially great value of land uncovered through drainage of Lake Okeechobee. Perhaps the holding assumes that if the state spends public money for (what was then seen as) a beneficial public project-partially draining the lake-the state, not

193. II 2 So. at $287-88$.

194. It was the plurality's treatment of the state as the cause of the avulsion that set up what the plurality called the "counter-intuitive" and "odd" rules of Florida law. Beach Renourishment, I30 S. Ct. at 26I2. This oddness in effect pushed matters to the brink-but in the end, the plurality said, deference to the Florida court's interpretation of Florida law saved the day. Id. at 2612-13.

195. For a detailed account of the history of Martin and its treatment by the Florida courts, see Sidney F. Ansbacher, What Did You Expect from Swamp Sales, A Happy Ending?, Const. L. Comm. NewSLETter (ABA), Sept. 20I0, at I I-I8 (concluding that Martin was no longer good law in Florida by the time the Beach Renourishment dispute arose).

196. Martin, I12 So. at $285-86$.

I97. Id. at 278-79.

I98. Id. at $286-87$. 
private owners fronting the lake, ought to get the benefit of the newly uncovered land. Moreover, in contrast to cases where change occurs gradually (as with accretion or erosion), it can be hard to identify what is causing it, and it is much simpler just to give the adjacent landowners the benefit of the accretion (and also the risk of erosion). But when the state drains a lake, it may be easier to point to the state as the cause of the change in the shoreline. ${ }^{199}$

In Board of Trustees of Internal Improvement Trust Fund v. Sand Key Associates, Ltd., ${ }^{20}$ decided in 1987 , the Florida Supreme Court faced the question of what to make of Martin. There, the state claimed that land that had accreted to beachfront property in fact belonged to the state. The state acknowledged that in general, accretion works to the benefit of the private property owners. But it said that Martin had recognized an exception: When the high tide line changes because of the state's actions, the state, not the private owner, gets the benefit of the accretion. Here, the state argued, the accretion that had expanded the beach was the result of a number of state projects-not beach reclamation projects, but the building of piers and docks, which can cause sand to accrete. It is only fair, the state argued, that the public should benefit from these state expenditures. ${ }^{201}$

The Florida Supreme Court ruled otherwise, holding that the private property owners owned the newly accreted beach. The opinion reads at times as if accretion is an absolute right under Florida law, but it did not quite so hold. The majority held that accretion from forces beyond the private property owner's control would move the property line seaward; only accretion caused by the landowner's own actions would accrue to the state. ${ }^{202}$ Essentially, it read Martin as limited to its facts, citing a brief concurrence to Martin's holding. It certainly did not read Martin as enunciating some general principle that artificial avulsions fix the property line.

The Sand Key majority's treatment of Martin evoked a strong dissent, which, after a detailed discussion of the case, concluded that it

I99. What actually lay behind the Martin court's thinking is not clear. While much valuable Florida real estate relies on state drainage projects to keep it dry and valuable, the particular parcels at issue in Martin might not fit this pattern. After a detailed account of the history of those parcels, Sidney Ansbacher argues that the land uncovered by the drainage project likely had little development potential (and indeed that a 1926 hurricane had put the land back underwater at the time Martin was decided). Ansbacher, supra note 195, at 16-18. He also argues that the terms on which Florida acquired Everglades land from the federal government included provisions for extensive installations of dikes and drains, which uniquely burdened the land (including the parcels at issue in Martin) once in private hands. Id. at I2-I6; see also id. at I9 ("Martin was based on such unique circumstances that it should not apply to beachfront parcels ....").

200. 512 So. 2d 934, 936 (Fla. 1987).

201. Id. at 937 ; id. at 947 (Ehrlich, J, dissenting).

202. Id. at $94 \mathrm{I}$. 
had decided a more general proposition: When the state is the cause of the change in property lines, the state owns any newly accreted or exposed land. While the dissent would have held for the state in Sand $K e y$, one thing it did not do is read Martin as setting a special precedent for artificial avulsions. Indeed, the dissent did not consider what happened in Martin-partial drainage of a lake-to be an avulsion, asserting that lake drainage on that scale could only be considered gradual. $^{203}$

In any event, the status of Martin under Florida law is far from clear. On the one hand, the reading the state gave Martin in 1987 is entirely plausible, and one could even read Sand Key as a kind of judicial taking of an established right - the right, that is, of the public to land that the expenditure of state funds creates. ${ }^{204}$ On the other, it is possible that Martin was simply clarified by the Florida Supreme Court in Sand Key.

In light of the Florida Supreme Court's previous engagement with Martin in Sand Key, there seems little reason to think that the Florida justices all somehow managed to overlook Martin. To do that they would have had to engage in an amazingly shallow reading of Sand Key (which they did cite). Martin was discussed (not just cited) in the Sand Key majority opinion and discussed quite extensively in the dissent. It seems much more plausible to suppose that members of the Florida Supreme Court saw no need to rely on Martin, a rather obscure case whose meaning and significance grew more obscure with Sand Key. Martin, after all, is critical only if one follows the Beach Renourishment plurality's formulation of the issue: What is the effect of an artificial avulsion (a lake draining or beach reclamation project) on the boundary between public and private? As we have seen, though, this question is not important in the way the Florida Supreme Court formulated the issue. That court regarded hurricanes as the avulsive acts, and took an

203. Id. at $945-47$ (Ehrlich, J., dissenting).

204. Of course, since this is a public right there is no sign that the plurality would find a constitutional violation; only private rights seem to matter here. One feature of a judicial takings doctrine is that the federal courts would scrutinize state courts if, in the course of defining property rights, they allegedly tipped the balance too far in favor of the public at the expense of "established" private rights. There would be no such scrutiny if they tipped the balance the other way. Nor would there be any clear-cut political accountability in the latter case. Some might think that Sand Key, which rejected the state's claim to own a newly created beach that came about because of accretion caused by the state's construction of a jetty, wrongly deprived the public of the fruits of its expenditures. See, e.g., Elizabeth Belsom, Case Comment, After Coastal Construction: Staking Out a Claim for Private Ownership, 40 U. FLA. L. REv. 457, 467 (1988) ("When the public discovers that costly government improvements actually grant away state property, the court may reconsider its holding."); Richard A. Epstein, The Public Trust Doctrine, 7 CATo J. 4I I, 419 (1987) ("The problem of disposing of public property ... raises the mirror image of public use and just compensation questions under the takings clause...."). A legislative reversal of Sand Key, however, would be immediately met with claims that the legislature had taken what Sand Key held to be private property. For an incisive analysis of this problem, see Shelby, supra note I42. 
approach that treated state law as an amalgam of common law and legislative policy, with deference but not utter obeisance toward the latter.

What is clear is that Martin's role as the case that saved the day for Florida in the U.S. Supreme Court makes sense only from the plurality's seemingly artless assumption that case law is all that matters. The utter convenience of this artlessness leads one to suspect that it is more than a little knowing.

\section{Two ExpLANATIONS}

A. PiQue

What might account for such a rogue opinion? Some of the explanation may lie in Justice Scalia's pique over beaches. It is not sand and sun that preoccupies him, though. It is how states determine public access to them. Justice Scalia seems particularly vexed by states that make this determination on a broad basis that encompasses all beaches, rather than employ doctrines that require a parcel-by-parcel determination.

\section{Beach and Shoreline Battles}

Many takings cases over the years have concerned access to beaches, demarcation of public and private rights at the shoreline, or the effect of development on access. ${ }^{205}$ Lucas $^{206}$ concerned restrictions on development on barrier islands; Beach Renourishment, ${ }^{207}$ restoration of beaches eroded by hurricanes; Tahoe-Sierra Preservation Council, Inc. $v$. Tahoe Regional Planning Agency, ${ }^{208}$ a temporary moratorium on residential development to study its impact on the Lake Tahoe Basin; and Nollan ${ }^{209}$ and Stevens, ${ }^{210}$ public access to beaches.

Questions of beach access have been the subject of intense conflict at the state level. Beach Renourishment itself arose from such a context. For years fights have been raging between beachfront property owners, who relish privacy and solitude, and the Destin city council, which favors public access to the beaches for the local population and for tourism. ${ }^{2 I}$

205. Cf. Christie, supra note 3 , at 72 ("From Nollan to... Beach Renourishment, the Supreme Court has chosen the nation's increasingly scarce sandy beaches as the stage for defining the constitutional limits of private property protection.").

206. 505 U.S. 1003 (1992).

207. 130 S. Ct. $2592(2011)$.

208. 535 U.S. 302 (2002).

209. Nollan v. Cal. Coastal Comm'n, 483 U.S. 825 (1987). See supra note 52.

2 I0. On Stevens, see infra notes $223-230$ and accompanying text.

2 I I. See Jennifer A. Sullivan, Laying Out an "Unwelcome Mat" to Public Beach Access, I8 J. LAND UsE 33 I (2003); S. Brent Spain, Note, Florida Beach Access: Nothing but Wet Sand?, I5 J. LAND UsE \& Envtl. L. I67, 187-89 (1999); Louis Cooper, Whose Beach Is It? Private Property Rights Clash with Public Interests on Destin Beaches, Florida Freedom NewsPapers, TheDestinlog.com, Aug. 21, 2009; 
Different states have created different frameworks to resolve conflicts between beachfront property owners, on the one hand, and cities and would-be beachgoers, on the other. We will not survey all the legal battles nationwide over access, but instead focus on two sets of issues relating to the rights of beachfront property owners versus those of the public.

One question is whether the public has any right of access to the dry sand beach when the property fronting the beach is privately owned. In some states, the answer is clearly yes. The New Jersey Supreme Court has held that the public does have rights of access to the dry sand portion of the beach, even if it is privately owned. ${ }^{212}$ In Oregon, Thornton gave a similar answer (based on a different legal theory). ${ }^{213}$

In other states the answer is no. Florida law, for example, provides no general easement or other public right of access to the dry sand portion of beaches. ${ }^{214}$ Michigan has a comparable limit. Property owners fronting the Great Lakes might in some sense have ownership right up to the water, but the Michigan Supreme Court ruled, as noted earlier, that the public has access to the shore right up to the ordinary high water mark. ${ }^{215}$ The rights do not extend beyond that, however.

In Texas, the answer is unclear. There may be rights of public access to the dry sand beach, possibly even a "rolling easement" (that is, one that changes with the movement over time of the mean high water mark) ${ }^{216}$ but a ruling of the Texas Supreme Court in November 2010 cast that notion into doubt. ${ }^{217}$

A second question is whether the rights of the public must be determined parcel-by-parcel, or whether they may be resolved on a more blanket basis through a general doctrine. In both Florida and New Jersey, the former is required. The dry sand portion of a private

Shannon Goessling, Destin Beachfront Property Rights Fight Isn't Over, TheDestinlog.com, Oct. 5, 20I I; see also Crystal Dunes Owners' Ass'n v. City of Destin, No. I I-I4595, 2012 WL I 293 II 7 (N.D. Fla. Apr. 17, 2012), aff'd, 2012 WL 1293117 (I th Cir. 2012), petition for cert. filed, U.S. No. 12-427 (Oct. 4, 2012); Fla. Att'y Gen., Regulation of Dry Sand Portion of Beach, AGO 2002-38 (May 24, 2002).

2I2. See Raleigh Ave. Beach Ass'n v. Atlantis Beach Club, Inc., 879 A.2d II2, I2I (N.J. 2005) ("Today, recognizing the increasing demand for our State's beaches and the dynamic nature of the public trust doctrine, we find that the public must be given both access to and use of privately-owned dry sand areas as reasonably necessary.").

213. State ex rel. Thornton v. Hay, 462 P.2d 671, 678 (Or. 1969) (custom).

214 See Spain, supra note 211 , at 169.

21 5. Glass v. Goeckel, 703 N.W.2d 58, 66-68 (Mich. 2005).

216. See Feinman v. State, 717 S.W.2d 106, 113 (Tex. App. 1986), writ ref'd n.r.e. (1987), reh'g on writ of error overruled (1987); Matcha v. Mattox, 7 I I S.W.2d 95, 100 (Tex. App. I986), writ ref'd n.r.e. (1986), cert. denied, 48I U.S. 1024 (1987); see also Gilbert L. Finnell, Jr., Public Access to Coastal Public Property: Judicial Theories and the Taking Issue, 67 N.C. L. REv. 627, 651-53 (1989).

217. Severance v. Patterson, 345 S.W.3d I8 (Tex. 2010). The court granted rehearing on the opinion; subsequently the question of mootness was raised. $I d$. at 50 . It was reinstated for rehearing in October 20I I. Severance v. Patterson, 20I I Tex. LEXIS 779 (No. 09-0387) (Oct. 7, 201 I). 
beachfront lot is privately owned, but the doctrine of prescriptive easements in favor of the public is recognized. To show such an easement requires evidence relating to the public's use of that particular lot. $^{218}$ Florida also recognizes the doctrine of customary rights of public access to beaches, but it requires that custom be established on a parcel-byparcel basis. ${ }^{219}$ In New Jersey, while the public trust doctrine applies to the entire dry sand beach, making public access relevant to all beachfront parcels, the court's approach requires some individualized showing that public access is "reasonably necessary." "220 In both Oregon and Michigan, in contrast, no case-by-case determination is needed. Texas law appeared to recognize a non-case-by-case "rolling easement" for public access to the dry sand beach, but that is in doubt. ${ }^{221}$

\section{Beach: Blanket or Case by Case?}

It is this second question that has particularly engaged the energies of property rights advocates. Indeed, the lengths to which Justice Scalia would go to impose a requirement that any public access to privately owned dry sand beaches be determined on a case-by-case basis is impressive. Consider his dissent (joined by Justice O'Connor) from the denial of certiorari in Stevens v. City of Cannon Beach in $1994 .^{222}$

Stevens arose out of the Oregon Supreme Court's handling of the public's right of access to beaches in State of Oregon ex rel. Thornton $v$. Hay, decided in 1969. ${ }^{223}$ As discussed earlier, in Thornton the Oregon Supreme Court found a broad public right of access to the dry sand portion of Oregon beaches, even though that portion was privately owned. ${ }^{224}$ It rested this holding on the English doctrine of custom, and further decided that the rights applied to all beaches in Oregon, without the need for a case-by-case determination.

No petition for certiorari was filed in Thornton, so the Supreme Court had no occasion at the time to rule on it. But in his dissent from the denial of certiorari in Stevens a quarter century later, Justice Scalia called Thornton a judicial "landgrab."225 What particularly incensed him was that in his view, the English doctrine of custom requires a factintensive, parcel-by-parcel determination of whether the public's rights

218. See Spain, supra note $2 \mathrm{I} \mathrm{I}$, at $18 \mathrm{I}-82$.

219. City of Daytona Beach v. Tona-Rama, Inc., 294 So. 2d 73, 77-78 (Fla. I974).

220. Raleigh Ave. Beach Ass'n v. Atlantis Beach Club, Inc., 879 A.2d I12, I21-24 (N.J. 2005) (canvassing factors related to the history of the property and the public's need for access). The Raleigh test differs from that of an easement in part by its strong emphasis on public need. But it is still a caseby-case determination.

22I. See supra note 217

222. 510 U.S. 1207 (1994).

223. State ex rel. Thorton v. Hay, 462 P.2d 67I (Or. I969).

224. See supra notes $\mathrm{I} 29-137$ and accompanying text.

225. Stevens, 510 U.S. at 1212 (Scalia, J., dissenting from denial of certiorari). 
have been established by custom. ${ }^{226}$ Yet, he said, "the Supreme Court of Oregon determined the . . . existence of these fact-intensive criteria ... in a discussion that took less than one full page of the Pacific Reporter.",227 He noted that the Oregon court's approach "reinforce[s] a sense that the court is creating the doctrine rather than describing it."

The very language Justice Scalia used suggests pique at the impertinence of a lower court that gave so little thought to what Justice Scalia believes to be the proper interpretation of the common law of custom. What reinforces this sense is the extraordinary lengths he would have had the Court go to deal with Thornton.

In his dissent from the denial of certiorari in Stevens, Justice Scalia did not assert that a judicial taking had occurred in the court below. The Stevenses, owners of a lot next door to the motel at issue in Thornton, ${ }^{229}$ had sought a permit to build a seawall on the dry sand beach. The permit was denied on the ground that it would interfere with public access to the full dry sand beach, and the Oregon courts upheld the denial based on Thornton. Noting that the Stevenses had not been parties to Thornton, Justice Scalia concluded that denying the permit on the authority of Thornton-without giving them a chance to show that the public had not customarily enjoyed access to their property - deprived them of their day in court, and so constituted a due process violation. ${ }^{23^{\circ}}$

Of course, if Thornton is correct as a matter of Oregon law, it is no denial of anyone's day in court to preclude a beachfront property owner from litigating the public's right of access to the dry sand beach. It is simply a matter of stare decisis, applying a generally applicable ruling by

226. He also seemed to view the court's ruling as an effort to make an end run around Lucas, through cheap invocation of the "background principles" exception. See id. at 1207 .

227. Id. at $\mathrm{I} 2 \mathrm{I} 2$.

228. Id. at 1212 n.4. Justice Scalia cast further doubt on Thornton by characterizing a later case, McDonald v. Halvorson, 780 P.2d 714 (Or. 1989), as having significantly qualified Thornton by adopting a tract-by-tract approach. Stevens, 510 U.S. at 1207 . Some commentators have made a similar assumption about Halvorson. See, e.g., Steven W. Bender, Castles in the Sand: Balancing Public Custom and Private Ownership Interests on Oregon's Beaches, 77 OR. L. Rev. 913, 943-44 (I998); Amnon Lehavi, Property Rights and Local Public Goods: Toward a Better Future for Urban Communities, 36 Urb. LAw. 1, 25 n.75 (2004); Erin Pitts, The Public Trust Doctrine: A Tool for Ensuring Continued Public Use of Oregon Beaches, 22 Envtl L. 73I, 738 (1992). This seems a rather strained reading of the case, which simply held that a cove near the beach, occasionally connected to the ocean, was not part of the beach and so not covered by the custom found by Thornton to apply to beachfront property. See Michael C. Blumm \& Erika Doot, Oregon's Public Trust Doctrine: Public Rights in Waters, Wildlife, and Beaches, 42 ENvTL L. 375, 377 n.7, 410 n.24I (2012) (arguing that Justice Scalia read Halvorson incorrectly); see also Jo Anne C. Long, Note, McDonald v. Halvorson: Oregon's Beach Access Law Revisited, 20 ENVTL. L. I00I, I03 I n.133 (1990) (effect of Halvorson on Thornton uncertain). In any case, it was not crucial to Justice Scalia's point, except perhaps to head off any thought that the Oregon court's holding a quarter century earlier had somehow become "established." That makes his willingness to wade into a contestable matter of state law all the more striking.

229. See Richard H. Chused, Cases, Materials and Problems in Property i 44 (3d ed. 2010).

230. Stevens, 510 U.S. at $1212-13$. 
the state's highest court to a particular parcel. But if Thornton is incorrect, and no public rights of access to any given parcel can be found under Oregon law without a case-by-case determination, then the Oregon courts' refusal to let the Stevenses present evidence concerning public access to their own parcel would be a patent injustice.

In short, Justice Scalia's dissent asked the full Court to determine whether a quarter century earlier Thornton had misconstrued Oregon law and then, if it had, to hold that petitioners had been denied the factspecific hearing to which the proper construction of Oregon law entitled them. From then on, any simple invocation of Thornton in state court would trigger a due process violation, vitiating its precedential status. Any state court holding on state property law could be retroactively demolished this way - no matter how long ago decided.

Given both Stevens and the general ire that broad custom-based rulings seem to provoke in property rights advocates, one prediction we make is that if judicial takings doctrine ever does command a majority on the Court, the single most likely outcome would be the national imposition of a case-by-case determination of access to privately owned dry sand beaches, precluding the use of general doctrines like custom or the public trust to find such access on a state-wide basis.

But wait, as the infomercials tell us - there's more.

\section{B. USURPATION}

It is by no means clear that other Justices share these views on beach access. Nor, obviously, can we be absolutely certain of Justice Scalia's. Thus there remains the question of how a judicial takings doctrine drew the votes of four Justices (with two others willing to subject state courts' definition of property law to new constitutional scrutiny). One clue lies in the very issue-federalism-of which the plurality was seemingly so oblivious.

Historically, increased federal judicial protection of states through federalism doctrines has tended to go hand in hand with tighter Supreme Court control over state law that is seen as posing a danger to property and contract rights. This association might seem surprising: Federalism doctrine would seem to be about opening up or at least preserving space for states to act, while stricter judicial scrutiny of property and contract matters would constrain states. But the Court, like Whitman, contains multitudes. ${ }^{231}$ The association is real.

23i. Walt Whitman, Song of Myself (i860), reprinted in Walt Whttman, Complete Poetry and Collected Prose 246 (1982):

Do I contradict myself?

Very well then I contradict myself,

(I am large, I contain multitudes.) 
In the Lochner era, the Court was assertive about striking down federal labor and other regulations on the ground that the Constitution deemed them local matters. ${ }^{232}$ Yet when states attempted to regulate wages and hours, the Court a number of times struck those efforts down as beyond states' power. ${ }^{233}$ Takings doctrine was one aspect of this constraint on states. It was in the midst of the Lochner era that the Court first articulated the regulatory takings doctrine..$^{234}$

The late eighties through the early nineties saw this same double conservative revolution. One part was the "[r]eturn of the Takings Clause" ${ }^{\prime 235}$ - a revival of increased scrutiny of state and local property regulations. Nollan and Dolan put restraints on local officials' ability to condition land use permits; ${ }^{236}$ First English Evangelical raised the prospect that landowners who successfully challenged land-use regulations would have to be compensated for any restrictions on the use of their property in the interim. ${ }^{237}$ And Lucas created a new category of taking for complete deprivation of value. ${ }^{238}$ At virtually the same time, the Court upended six decades of deference to Congress and undertook a newly heightened scrutiny of federal laws under the Commerce Clause. ${ }^{239}$ It also breathed new life into the Tenth Amendment, fashioning an "anti-commandeering" principle protecting state and local officials and legislatures from the burdens of implementing federal legislation. ${ }^{240}$

Neither part of this recent conservative revolution has quite fulfilled its initial promise. Raich and Comstock both upheld federal authority. ${ }^{241}$ Star of the revived Takings Clause, Lucas included an exception allowing even a complete deprivation of value to stand if justified by background principles of state nuisance and property law, ${ }^{242}$ an exception that

232. See, e.g., Carter v. Carter Coal Co., 298 U.S. 238 (1936).

233. See, e.g., Coppage v. Kansas, 236 U.S. I (1915); Adair v. United States, 208 U.S. I6I (I908); Lochner v. New York, I98 U.S. 45 (1905).

234 See supra notes $38-40$ and accompanying text (discussing Pennsylvania Coal).

235. Coyle, supra note 159 , at 818 .

236. Dolan v. City of Tigard, 512 U.S. 374 (1994); Nollan v. Cal. Coastal Comm'n, 483 U.S. 825 (1987). See supra note 52.

237. First English Evangelical Lutheran Church v. Los Angeles Cnty., 482 U.S. 304 (1987).

238. Lucas v. S. Carolina Coastal Council, 505 U.S. 1003 (1992).

239. United States v. Morrison, 529 U.S. 598 (2000); United States v. Lopez, 5 I4 U.S. 549 (I995). See supra notes $103-109$ and accompanying text.

240. Printz v. United States, 52 I U.S. 898 (1997); New York v. United States, 505 U.S. I44 (1992). For an incisive analysis of the relationship between the Court's takings jurisprudence and federalism trends in environmental regulation as of two decades ago, see Linda A. Malone, The Coastal Zone Management Act and the Takings Clause in the 199o's: Making the Case for Federal Land Use to Preserve Coastal Areas, 62 U. Colo. L. Rev. 71 I , 746-73 (1991).

24I. United States. v. Comstock, 130 S. Ct. I949, 1965 (2010); Gonzales v. Raich, 545 U.S. I, 2 (2005).

242. Lucas, 505 U.S. at $103 \mathrm{I}-32$. 
threatens to turn into a black hole from which no takings claim escapes. ${ }^{243}$ Both Kelo and Beach Renourishment represent the promise and (so far) limits of this conservative revolution: In both cases the Court came within one vote of a major conservative ruling on property rights protections, largely ignoring federalism issues.

Thus the desire to cut Congress down to size through judicial enforcement of federalism in Commerce Clause cases is not grounded in strong confidence in state and local government. On the contrary, conservative property rights activists manifest an almost paranoid fear that state courts will be drawn into or even actively collaborate with state legislative efforts to undermine property rights. Beach Renourishment is best understood as an attempt to enlist the Court in the conservative property rights movement's campaign to limit democratic control over natural resources. ${ }^{244}$

This understanding may help to explain the plurality's approach to state common law, which, as noted earlier, erases the role of legislatures. For conservatives, the kind of state legislative-judicial interaction we have described-particularly when marked by judicial deference toward the legislature-is a source of deep suspicion. ${ }^{245}$ The concern is that a court may attempt to do for free what the legislature would have to undertake with compensation to property owners if it made the change itself.

In his influential article on judicial takings, for example, Barton Thompson argues that the doctrine is needed to head off the possibility of something like collusion between the legislature and the judiciary (or at least informal direction of the latter by the former). Rather than formally use eminent domain to take away rights of beachfront property owners, a state legislature might announce a new policy (for example, the importance of public access to beaches), and the state courts would

243. See Hope M. Babcock, Has the U.S. Supreme Court Finally Drained the Swamp of Takings Jurisprudence?: The Impact of Lucas v. S. Carolina Coastal Council on Wetlands and Coastal Barrier Beaches, I9 HARv. Envtl. L. Rev. I (1995); Michael C. Blumm \& Lucus Ritchie, Lucas's Unlikely Legacy: The Rise of Background Principles as Categorical Takings Defenses, 29 Harv. EnvtL. L. Rev. 321 (2005).

244. Cf. Laura S. Underkuffler, Tahoe's Requiem: The Death of the Scalian View of Property and Justice, 2 I CONST. Comment. 727, 749 (2004) ("[U]nder the Scalian view, consideration of asserted public interests in the broad run of takings cases is not simply ignored-it is, in fact, illegitimate.").

245. See supra Part I.B.2. To some extent this erasure might stem from Justice Scalia's intellectual outlook. In Beach Renourishment, Justice Scalia presented the common law as originally timeless and unchanging, though of course subject to modification by statute. As he put it, "the Constitution was adopted in an era when courts had no power to 'change' the common law." Stop the Beach Renourishment, Inc. v. Fla. Dep't. Envtl. Prot., I30 S. Ct. 2592, 2606 (201 I). That power, in his view, was engrafted onto the common law in the nineteenth century. Id. at 2606-07. He thus presented state courts' power to change the common law almost as an alien hybrid which persists today, but which must be regarded with great caution, especially when it comes to property rights. Id. For an insightful analysis, see Mulvaney, supra note 3 . 
follow up by issuing rulings that defined away any existing private rights that stood in the way of public access. ${ }^{246}$ Other commentators have raised similar possibilities. ${ }^{247}$ And the theme of judicial perfidy inspired by or

\footnotetext{
246. See Thompson, Judicial Takings, supra note 4 , at 1487 :

[J]udicial decisions in a number of states appear to be influenced on occasion by legislative pressure and direction. Legislatures often send clear public messages, by legislation, resolution, or other means, concerning the direction the state courts should take. Unless legislatures are sending the messages purely as a show for the voters, the legislatures presumably believe that such messages have an impact. Indeed, the desired results are frequently obtained. In a number of recent cases raising claims of judicial takings, for example, the state court announced its apparent shift in law only after the legislature passed or proposed legislation clearly point out the direction it wished the court to take;
}

see also Karen A. Negris, Access to New Jersey Beaches: The Public Trust Doctrine, 20 Colum. J.L. \& Soc. ProBs. $437,45^{8}$ n.I46 (1986) (suggesting that the New Jersey Supreme Court's reference to legislative policy in deciding public trust doctrine case reflected a judicial effort "on behalf of the legislature" to evade the strictures of the Takings Clause); Thompson, Judicial Takings, supra note 4, at $145^{\mathrm{I}}$ ("Courts have the doctrinal tools to undertake many of the actions that legislatures and executive agencies are constitutionally barred from pursuing under the takings protections-and pressure is mounting for courts to use those tools."). Other commentators, while not necessarily seeing wrongful collusion, view anything other than reining in the legislature as an improper role for the courts when it comes to property rights. See James L. Huffman, Avoiding the Takings Clause Through the Myth of Public Rights: The Public Trust and Reserved Rights Doctrines at Work, 3 J. LAND UsE \& ENVTL. L. I7I, 210 (1987) ("The legislature needs no assistance from the courts ... [Their] task ... is to protect individuals from the efforts of the legislature ....").

247. One commentator raised this scenario after Lucas:

Suppose that the next time South Carolina wishes to restrict the use of property like Lucas's, instead of passing a new statute or issuing a new administrative regulation to accomplish the restriction directly, the legislature simply authorizes private law suits to be brought by the Coastal Council, or even private conservation groups, for the benefit of the public, to enjoin what the Council believes to be harmful or noxious uses of property under the state's background principles of property law. The state court, then, is free to take this winking and nudging from the legislature and effectively fashion new common law rules that restrict the owner's use of his property, denying compensation based on the claim that the new rule is merely a background principle of the state's law - that there was no property right there to begin with.

Sarratt, supra note 4, at I492; see also id. at 1493 (worrying about "the Lucas loophole").

Another expressed similar skepticism about a Texas lower court's upholding of a Texas statute, the Texas Open Beaches Act, against takings challenges, arguing that the court was motivated in part by a "desire to protect the government from claims of legislatively enacted takings of property interests." David J. Bederman, The Curious Resurrection of Custom: Beach Access and Judicial Takings, 96 Colum. L. Rev. 1375, 1413-17 (1996) (arguing that, in the Texas Open Beaches Act, the legislature modified the common law doctrine of customary access to beaches by providing that it protected the public at large (all Texans), not just local residents, but that the Texas Court of Appeals wrongly presented the legislation as simply codifying the customary law). Bederman's position is that the doctrine of custom in common law had largely been rejected by the turn of the twentieth century because it created so much uncertainty as to property rights that it inhibited development, id. at 1398407 , and that upon its revival in Texas it protected only residents living near that beach, not all Texans (otherwise it would be "too indefinite"). See id. at I4I5-I6. Similarly, the Thornton case, discussed earlier, becomes one in which "judicial activists recognize[d] custom-based property rights as an easy, and cheap, means of vesting a public interest in a valuable resource." $I d$. at $1380,1417-26$; see also id. at 1449 (calling Thornton and similar cases "sua sponte assertions of public interests in private property" and asserting that the only proper way to handle beach access questions is by "jury verdicts 
working in tandem with legislative greed was prevalent in many of the briefs filed with the Court in Beach Renourishment. ${ }^{248}$

This fear of state legislatures (and state legislative-judicial collusion) seems to have led the Beach Renourishment plurality to erase Congress's role as well. Lurking within the plurality's approach to the states is a notably robust view of the Court's role in the separation of powers. That the separation of powers and federalism can intersect is no surprise. Writing for the Court in Printz, Justice Scalia concluded that a federal statute requiring state officials to implement a federal gun control law trespassed on state sovereignty under the Tenth Amendment. ${ }^{249} \mathrm{He}$ went on to argue that placing enforcement of a federal statute in the hands of state officials, whom the President does not control, infringes on the President's executive powers under Article II. ${ }^{250}$ Of course, federalism is complex: It may have complemented protection of executive power in Printz, but fifteen years later Justice Scalia invoked it in support of letting the states undercut President Obama's policy on enforcement of federal immigration laws (a policy the Justice pronounced "unwise"). ${ }^{251}$

The intersection of federalism and separation of powers plays out in another way. The concern for each may be selective. Consider the Court's attitude to the Coastal Zone Management Act ("CZMA"). ${ }^{252}$ The most comprehensive Congressional expression of federal policy regarding coastal zone management, the CZMA was enacted in 1972 as part of President Nixon's "New Federalism" model of cooperative federalism. ${ }^{253}$

endorsing proofs of a localized custom").

248. See, e.g., Petitioner's Reply to Briefs in Opposition, Stop the Beach Renourishment, Inc. v. Fla. Dep't of Envtl. Prot., I30 S. Ct. 2592 (2010) (No. 08-II5I), 2009 WL I370I60, at *3 (The Florida court acted "to allow the state to continue sponsoring beach renourishment projects"); id. at *I 2 ("The Florida Supreme Court's opinion is a product of judicial engineering to achieve a desired policy result."); id. at * ${ }^{2} 3$ ("The ... ruling . . is repulsive ...."); Brief Amicus Curiae of Cato Inst. et al. in Support of Petitioner, Stop the Beach Renourishment, Inc. v. Fla. Dep't of Envtl. Prot., I30 S. Ct. 2592 (2010) (No. 08-115I), 2009 WL 2588282, at *6 ("The federal courts' reluctance to apply the judicial takings doctrine sends a message to state legislatures to forego legislative changes in the definition of property rights, in favor of encouraging state courts to effect the same policy without exposing the state to liability for just compensation.").

249. Printz v. United States, 52 I U.S. 898, 935 (1997).

250. Id. at 923 ("[The] unity [of the executive branch] would be shattered, and the power of the President would be subject to reduction, if Congress could act as effectively without the President as with him, by simply requiring state officers to execute its laws."). See U.S. ConsT. art. II, § 3 ("[The President] shall take Care that the Laws be faithfully executed ....").

25I. Arizona v. United States, I32 S. Ct. 2492, 252 I (2012) (Scalia, J., concurring in part and dissenting in part) (criticizing the president's policy as a failure to enforce the law, and arguing that in light of state sovereignty under the Constitution, Arizona's immigration enforcement law should not be preempted).

252. I6 U.S.C. $\S \S 145 \mathrm{I}-65$ (2006)

253. See Andrew S. Jessen, Comment, Louisiana and the Coastal Zone Management Act in the Wake of Hurricane Katrina: A Renewed Advocacy for a More Aggressive Use of the Consistency Provision to Protect and Restore Coastal Wetlands, 12 OCEAN \& COASTAL L.J. I33, I34-35 (2006); 
While state and local land use policy has a significant overlay of federal regulation, particularly environmental regulation, the CZMA makes clear that one area that the federal government leaves largely to the states alone is rights of access to beaches. The CZMA declares a national policy to provide for "public access to the coasts for recreation purposes" 554 -by "encourag[ing] and assist[ing] the states to exercise effectively their responsibilities in the coastal zone through the development and implementation of management programs to achieve wise use of the land and water resources of the coastal zone."255 In I990, Congress amended the CZMA to encourage states to take the public trust doctrine into account in their coastal zone management planning. ${ }^{256}$ Significantly, the CZMA was enacted after the failure of a proposed National Open Beaches Act to gain passage in Congress. The various versions of the proposed act would have declared access to beaches a national interest and provided for federal action to protect or create beach access. ${ }^{257}$

The CZMA seeks to achieve its purpose by providing states with funds to develop these programs. For example, states are expected to develop plans to protect public access to beaches; as part of that planning, each state defines, within some broad guidelines, what the beach (public and private) is. ${ }^{258}$ Granted, the CZMA provides for some conditions on federal funding and oversight of state programs developed with it. What has resulted is what two commentators call a "[c]ooperative federalism" with states as "dominant partners," "capitulation of federal authority." ${ }^{260}$ States that develop programs, for

Laurina M. Spolidoro, Area Contingency Plans: Is the Coastal Zone Management Act on a Collision Course with Unfettered Oil Spill Response?, 27 WM. \& MARY ENVTL. L. \& PoL'y Rev. 755, 759-60 (2003). But see Sam Kalen, The Coastal Zone Management Act of Today: Does Sustainability Have a Chance?, I5 Southeastern ENvTL. L.J. I91, 204 (2006) (noting efforts of the Nixon administration to undermine CZMA after its passage).

254. I6 U.S.C. \& $1452(2)(E)$.

255. Id. \& $1452(2)$.

256. See, e.g., Kalen, supra note 253 , at 219.

257. See Marc R. Poirier, Environmental Justice and the Beach Access Movements of the r97os in Connecticut and New Jersey: Stories of Property and Civil Rights, 28 CoNN. L. REv. 719, 748-49 (1996); Robert Thompson, Affordable Twenty-Four Hour Coastal Access: Can We Save a Working Stiff's Place in Paradise?, 12 OCEAN \& CoAstal L.J. 91, 104-06 (2006). For a statement by the CZMA's main sponsor, see Robert C. Eckhardt, A Rational National Policy on Public Use of the Beaches, 24 SYRacuse L. Rev. 967 (1973). In 1974, Congress also rejected a proposed National Land Use Policy Act, which would have significantly federalized land use planning. See Poirier, supra, at 750-51; see also Ludwik A. Teclaff \& Eileen Teclaff, Saving the Land-Water Edge from Recreation, for Recreation, 14 ARIZ. L. REv. 39, 59-60 (1972).

258. See I6 U.S.C. \& I455(d); Coastal Zone Management Program Regulations, is C.F.R. $\$ \S 923.24$ (a), 923.3I(5) (2012); see also S. REP. No. 94-277, at 32-33 (1976).

259. George Cameron Coggins \& Robert L. Glicksman, Public Natural Resources Law \& $5: 6$ (2d ed. 2012).

260. Bruce Kuhse, The Federal Consistency Requirements of the Coastal Zone Management Act of I972: It's Time to Repeal This Fundamentally Flawed Legislation, 6 OCEAN \& COASTAL L.J. 77, I08 
example, are assured that federal activities will be typically consistent with those programs.

In enacting the CZMA, then, Congress displayed notable deference to the states. ${ }^{262}$ To be sure, its decisions about when to defer to states may not always look the most rational to everyone. Coastal zone areas are clearly ones of national, not merely local, importance, and Congress's authority to act is unquestioned. As two commentators put it, "[u]nder the United States Constitution, the federal government's authority over coastal and marine resources is clearly paramount." ${ }^{263}$ We see no constitutional reason why Congress could not enact a statute guaranteeing, and regulating the terms of, public access to beaches (though one suspects that such a statute would evoke cries of "socialism"). ${ }^{264}$ Yet under the CZMA's consistency requirement, the usual relationship - federal supremacy over state law - is inverted, with state law governing federal agency activity in matters covered by the plan. ${ }^{265}$ Some commentators have argued that Congress has tipped the balance too far in favor of state interests in coastal zones. ${ }^{266}$ Indeed, as global warming threatens the coastlines, the need for federal intervention may grow stronger. ${ }^{267}$

(2001). For a response, see John A. Duff, The Coastal Zone Management Act: Reverse Pre-emption or Contractual Federalism?, 6 OCEAN \& COASTAL L.J. IOg (200I) (rejecting a "reverse pre-emption" critique of the CZMA); see also Nat'l Oceanic \& Atmospheric Admin. \& Coastal States Org., ENVISIONING OUR COASTAL FuTURE 7, II (2007), available at http://coastalmanagement.noaa.gov/czm/ czma_vision.html (describing the federal consistency requirement as a "states' rights" measure).

261. See, e.g., Edward M. Cheston, An Overview and Analysis of the Consistency Requirement Under the Coastal Zone Management Act, Io U. BALT. J. ENvTL L. 135 (2003); Jessen, supra note 253, at $138-40$; Kalen, supra note 253 , at $201-03$.

262. Indeed, it displayed rather more deference than did the Court in Lucas in invalidating a regulation issued by the South Carolina Coastal Council, which the state had established in response to the CZMA. See Regina McMahon, The Lucas Dissenters Saw Katrina Coming: Why Environmental Regulation of Coastal Development Should Not Be Characterized as a "Taking", I5 PENN ST. ENvTL. L. REv. 373, 387 (2007); see also Nollan v. Cal. Coastal Comm'n, 483 U.S. 825 (1987).

263. Thomas J. Schoenbaum \& Frank Parker, Jr., Federalism in the Coastal Zone: Three Models of State Jurisdiction and Control, 57 N.C. L. REv. 23I, 232 (1979).

264. We refer here to Congress's power over the coastal areas, including its Commerce Clause power. Of course, as with any other federal statute, it would need to comply with the requirements of the Bill of Rights, including the Takings Clause. We simply disclaim any assertion that the Constitution makes beach access an exclusively state matter.

265. On the consistency requirement, see Patrick J. Gibbons, Too Much of a Good Thing? Federal Supremacy \& the Devolution of Regulatory Power: The Case of Coastal Zone Management Act, 48 Naval L. Rev. 84 (2001); Kalen, supra note 253.

266. See Gibbons, supra note 265 , at 86 ("This article argues that in pursuing an arrangement that purports to restore traditional federal-state distributions of power, the Coastal Zone Management Act inadvertently goes too far and gives the states excessive power.").

267. Moreover, the CZMA has not been particularly effective in increasing public access to beaches. See James M. Kehoe, The Next Wave in Public Beach Access: Removal of States as Trustees of Public Trust Properties, 63 Fordham L. Rev. 1913, 1946-5I (1995). 
On the other hand, Congress approved the Religious Land Use and Institutionalized Persons Act in $2000 .{ }^{268}$ That Act intrudes deeply into state and local land use law. State and local zoning decisions or plans that frustrate land use by religious institutions can be challenged in federal court under heightened review. ${ }^{269}$ With a politics that regularly requires presidential candidates to make public avowals of faith, it is not clear why threats to religious freedom should be regarded as so great as to necessitate such a deep intrusion into state land use planning.

What matters, though, is that these are choices that Congress has made. Congress does, after all, have the power to authorize state jurisdiction over issues that fall within the power of the federal government to regulate. ${ }^{270}$ Granted, the CZMA does not rise to the level of such an express authorization. But our point is different. Congress has largely left the matter of beach access to the states. On what basis, then, might the Court justify expanding the scope of the Takings Clause to federalize beach access issues? "Judicial arrogance" is not a pretty answer, but it is a hard one to dismiss.

The unilateral extension of federal judicial authority certainly cannot be grounded on some consistent preference for federal authority. At times (when convenient?) the Court has loudly proclaimed its great reluctance, in interpreting federal statutes, to impute to Congress any intent to impinge on traditional state authority. ${ }^{27}$ In Rapanos $v$. United States, ${ }^{272}$ for example, Justice Scalia - writing for the same plurality as in Beach Renourishment-expressed concern over the expansion of federal environmental regulation, displacing "the States' traditional and primary power over land and water use."273 According to Justice Scalia, the

268. 42 U.S.C. \$ $2000 c c-\mathrm{I}-\mathrm{cc}-5$ (2006).

269. To be sure, there is little evidence in the legislative history that Congress actively thought about federalism issues when it approved the Act. See Marci A. Hamilton, Federalism and the Public Good: The True Story Behind the Religious Land Use and Institutionalized Persons Act, 78 IND. L.J. $311,341-45$ (2003). But inattention to state and local interests in some contexts, in light of great solicitude for them in others, speaks volumes.

270. For example, Congress has the power to authorize any state or local law found to violate the dormant commerce clause. See, e.g., C \& A Carbone, Inc. v. Clarkstown, 51 I U.S. 383, 410 (1994) (O'Connor, J., concurring).

271. E.g., United States v. Bass, 404 U.S. 336, 350 (1971) (narrowly construing a federal firearms statute to avoid potential Commerce Clause problems).

272. 547 U.S. 715 (2006).

273. See id. at $737-38$ :

Even if the phrase "the waters of the United States" were ambiguous as applied to intermittent flows, our own canons of construction would establish that the Corps' interpretation of the statute is impermissible.... [T] The Government's expansive interpretation would "result in a significant impingement of the States' traditional and primary power over land and water use" [(quoting Solid Waste Agency v. U.S. Army Corps of Engineers, 532 U.S. I59, I74 (200I))]. Regulation of land use, as through the issuance of the development permits sought by petitioners in both of these cases, is a quintessential state and local power.... We ordinarily expect a "clear and manifest" statement from 
federal statute at issue there did not encompass the wetlands the Corps of Engineers sought to protect. ${ }^{274}$ While asserting that his sole aim was to respect the language of the federal statute, he did not hide his contempt for the federal agency, accusing the U.S. Army Corps of Engineers of acting like an "enlightened despot.,"275 Restraint is for the political branches, judicially enforced if need be, but-in the hands of the Beach Renourishment plurality -irrelevant to the Court's own predilections. ${ }^{276}$

The judicial federalism project on which the Court has embarked since Lopez in I995 rests on an assumption of what Justice O'Connor called Congress's "underdeveloped capacity for self-restraint.",277 For the members of the Court to enshrine a judicial takings doctrine in an area that the federal political branches have largely left to the states strongly suggests that that assumption would be better directed to the Court itself. It is not just states whom the Court cuts down to size with its takings jurisprudence; it is Congress as well. This combination should be called what it is: usurpation.

\section{Conclusion: One Vote (Away)}

Rather than hurl the charge of "rogue" at the plurality, why not accuse it of promoting conservative judicial activism? Speaking of Bush v. Gore a decade ago, Cass Sunstein focused on its sole virtue: "[I]t should finally be possible for the American public to disregard the ludicrous Republican rhetoric about 'liberal judicial activism'...."278 "We are now," he went on, "in the midst of an extraordinary period of right-wing judicial activism .... [in which] the Court seems oblivious to the extent to which its own political preferences are playing a role" in its decisions. ${ }^{279}$

Would that it were so. "Judicial activism" would be preferable to an opinion for which the pique of a right-wing Justice is as good an explanation as principled politics. We do not doubt that Justice Scalia

Congress to authorize an unprecedented intrusion into traditional state authority.

274. Id. at 753 .

275. Id. at 7 I9.

276. Thus Chief Justice Roberts, joined by Justices Scalia and Alito, would have the Court secondguess local government decisions about how to handle tax refunds, relying on the minimum rationality standard of Equal Protection doctrine. See Armour v. City of Indianapolis, 132 S. Ct. 2073, 2084 (2012) (Roberts, C.J., dissenting). With its echoes of the admonition in Bush $v$. Gore that the Court's equal protection holding was for that case only, see Bush v. Gore, 53I U.S. 98, I09 (2000), the Chief Justice's assurance that such intrusive federal review of local government decisions would be undertaken only "every generation or so," is anything but reassuring. Armour, I32 S. Ct. at 2087.

277. Garcia v. San Antonio Metro. Transit Auth., 469 U.S. 528, 588 (1985) (O'Connor, J., dissenting).

278. Cass R. Sunstein, Does the Constitution Enact the Republican Party Platform? Beyond Bush v. Gore, in Bush v. Gore: The Question of Legrtimacy 176, 177 (Bruce Ackerman ed. 2002).

279. $I$ d. at 178 . 
believes that many state courts have failed miserably in handling the common law of custom when it comes to beach access, and we are aware that some (by no means all) scholars are critical of state courts' handling of the matter as well. ${ }^{280}$ But, taking a page from Justice Scalia's own penchant for bluntness, who is he to criticize? As a self-appointed state court judge in Beach Renourishment, he failed to impress. More important, the Takings Clause does not cast federal judges in this role. Why take it on?

Or rather, why not? There is a morbid fascination to witnessing the professional frolics of a Justice apparently intent on demonstrating that the original intent behind "good Behaviour" really does mean life tenure no matter what ${ }^{281}$-using the bench to denounce President Obama's "Dream Act"-style executive order on immigration enforcement, ${ }^{282}$ duckhunting with Vice President Cheney and then dismissing the questions raised about his conduct as the product of "so-called investigative journalists" prone to raise "silly" or "baseless allegations of impropriety" that produce "inaccurate and uninformed opinion," ${ }^{283}$ giving critics of

280. Bederman, supra note 247 , represents perhaps the most thorough example of such a critique; see David L. Callies, Custom and Public Trust: Background Principles of State Property Law, 30 ENVTL. L. RPTR. I0003, IOOI9-20 (2000). These critiques rest on a profound distrust of evolution and change in the common law-or as two commentators succinctly put it, "[c]ustom [m]ust [b]e [r]eturned to the Blackstonian [f]ramework." See David L. Callies \& J. David Breemer, Selected Legal and Policy Trends in Takings Law: Background Principles, Custom and Public Trust "Exceptions" and the (Mis)use of Investment-Backed Expectations, 36 VAL. U. L. REv. 339, 369 (200I); id. at 372 ("The [p]ublic [t]rust [doctrine] [s]hould [b]e [r]estricted to [i]ts [t]raditional [s]cope."); id. at 379 (arguing that "newly discovering or expanding such principles" is incompatible with property rights); see also Callies, supra, at 10020 (treating Blackstone's characterization of the law of custom not simply "as a matter of reason, but as a matter of law since he is almost always cited in the reported American cases on custom and customary law"). For a different view of the common law, see Blumm \& Ritchie, supra note 243 , at $343-44$.

28I. U.S. Const. art. III, § I ("[Federal] judges.... shall hold their Offices during good Behaviour...."). See United States v. Will, 449 U.S. 200, 217-19 (1980). Frolics are not, of course, listed in the catalog of impeachable offenses. U.S. Const. art. II, \$ 4 ("Treason, Bribery, or other high Crimes and Misdemeanors").

282. Arizona v. United States, I32 S. Ct. 2492, 2521 (2012) (Scalia, J., concurring in part and dissenting in part). See Adam Liptak, Court Splits Immigration Law Verdicts; Upholds Hotly Debated Centerpiece, 8-0, N.Y. TIMEs, June 26, 2012 at AI(L) ("Justice Antonin Scalia summarized his dissent from the bench, a rare move that indicated his deep disagreement. Rarer still, he criticized a policy that was not before the court: President Obama's recent announcement that his administration would not deport many illegal immigrants who came to the United States as children."); David G. Savage, Justice Scalia Went Too Far This Time, Some Say; The Conservative's Dissent on Arizona's Immigration Law Is Called Strident and Partisan, Even for Him, L.A. Times, June 27, 2012, at A13. For reactions, see E.J. Dionne, Jr., Too Political for a Justice, WASH. Post, June 28, 2012, at A21; Ed Whelan, E.J. Dionne's Anti-Scalia Tirade, NAT'L REv. ONLINE (June 27, 2012), http:/www. nationalreview.com/bench-memos/304I85/ej-dionne-s-anti-scalia-tirade-ed-whelan.

283. Cheney v. U.S. Dist. Ct. for D.C., 54I U.S. 913, 927, 928 (2004) (Scalia, J., denying motion to recuse). See Michael Janofsky, Scalia's Trip with Cheney Raises Questions of Impartiality, N.Y. TIMES, Feb. 6, 2004, at AI4; Adam Liptak, In Re Scalia the Outspoken v. Scalia the Reserved, N.Y. Times, May 2, 2004 at Ai; James B. StaAB, The Political Thought of Justice Antonin Scalia: A Hamiltonian oN THE SUPREME COURT 315-17 (2006). 
Bush v. Gore a contemptuous "[g]et over it," Party politicians in a (sadly or mercifully? - it's hard to tell) closed caucus, ${ }^{285}$ and hysterically denouncing an act of judicial modesty in takings law as a modern Dred Scott. ${ }^{286}$ The list is endless. ${ }^{287}$ The spectacle of an exalted federal judge showing state court judges that he can best them at their own game apparently has a similar carnival attraction. In some parallel universe where Sarah Palin wins the presidency to satisfy the public's morbid curiosity, there is much to be said for the prospect of many more years of such self-assured performances, and it seems safe to assume that we have not seen the last of them. ${ }^{288}$

In the real world, however, the plurality opinion in Beach Renourishment is more than a display of pique. It epitomizes a Court never more than one vote away (if that) from an arrogance slipping out of all restraint. Nor are we fully persuaded of what Sunstein so generously assumed ten years ago-that the Court is in fact oblivious to its conservative political agenda.

284. Joan Biskupic, American Original: The Life and Constitution of Supreme Court Justice Antonin Scalia 9 (2009); Frank Cerabino, Student Fails to Persuade Justice Scalia, Palm Beach Post (FLA.), Feb. 8, 2009, at BI; see BISKUPIC, supra, at $35^{6}$ (dismissing a student's question about televising Supreme Court proceedings as a "nasty, impolite question").

285. See George Bennett, Michelle Bachmann Delivers Tea Party Message in Palm Beach County, Fort Lauderdale Sun-Sentinel, Mar. 4, 201 I (Tea Party Caucus leader's remarks criticizing "judicial activism"); Adam Liptak, Tea-ing up the Constitution, N.Y. TIMES, Mar. 43, 2010, at PI(L) (noting the emphasis of the Tea Party movement on "the Constitution's constraints on federal power"). Nor does it seem consistent with Justice Scalia's remarks to the Caucus. See Felicia Sonmez, Scalia's ClosedDoor Session with Lawmakers Proves Light on Politics, Attendees Say, WASH. Posr (Jan. 24, 20II) http://voices.washingtonpost.com/44/20I I/or/scalias-closed-door-session-wi.html (discussing Rep. Don Manzullo's quotation of Justice Scalia's remarks: “Congress is 'the 900-pound gorilla' of the three branches").

286. Debra Cassens Weiss, Scalia Lumps Kelo Decision with Dred Scott and Roe v. Wade, ABAJourNaL.com (Oct. I9, 20I I), http://www.abajournal.com/news/article/scalia_lumps_kelo_decision_ with_dred_scott_and_roe_v._wade (denouncing Kelo as the modern incarnation of Dred Scott (along with Roe v. Wade)).

287. See Transcript of Oral Argument at 20, Toledo-Flores v. United States, 549 U.S. 69 (2006) (No. 05-547) (asserting during oral argument that Mexican petitioner must be drinking tequila); Transcript of Oral Argument at 9, Lawrence v. Texas, 539 U.S. 558 (2003) (No. 02-I02) (asking whether "flagpole sitting" is "a fundamental right" in oral argument); BISkUPIC, supra note 284, at 312-13. Cf. Antonin Scalia, The Disease as Cure, 1979 WASH. U. L.Q. I47, 153 (commentary by thenProfessor Scalia unfavorably comparing Justice Powell's concurrence in Regents of Univ. of Cal. $v$. Bakke, 438 U.S. 265 (1978), with Nazi racial doctrine). See generally Erwin Chemerinsky, The Jurisprudence of Justice Scalia: A Critical Appraisal, 22 U. HAW. L. REv. 385, 399-400 (2000).

Perhaps there is a public service in these performances, if we regard them as a real-world test of the power of judicial "[e]xpressions of certitude" to generate a "neutrality crisis" in public perceptions of the judiciary. See Dan M. Kahan, Foreword: Neutral Principles, Motivated Cognition, and Some Problems for Constitutional Law, I25 HARv. L. Rev. I, 57, 58, 6I (2011).

288. The haunted sense of self-doubt that Justice Scalia attributed to Chief Justice Roger Taney is not likely to eclipse the Justice's self-luster. See Planned Parenthood v. Casey, 505 U.S. 833, I00I (1992) (Scalia, J., dissenting in part) (describing Roger Taney's portrait at Harvard Law School). 
Yet the "ludicrous Republican rhetoric" is still with us, as the 2012 presidential campaign has reminded us. Predictable fulminations about liberal judges out of control followed the Ninth Circuit's decision that California's Proposition 8 was unconstitutional. ${ }^{289}$ It is worth putting these fulminations in context, to see the real danger they pose: distraction. Responding to right-wing attacks on the judiciary over abortion, gay rights, and religion decisions with reminders of the importance of an independent judiciary ${ }^{290}$ may too easily divert attention from the real dangers. To put it another way, there is no reasonable prospect that Congress is going to begin impeaching judges for supposedly liberal decisions, and spending time worrying about the more extreme proposals seems pointless. There is, however, more than a minor prospect that the conservative agenda represented in the plurality opinion will gain five votes in important cases, whether from Justice Kennedy (a possibility strongly suggested by his vote to strike the entire health care law ${ }^{291}$ ) or a new appointment.

Important as an independent judiciary is, focusing on the threat that conservative judicial usurpation poses to democracy in the areas of economic regulation, executive power, campaign finance, and environmental protection - and responding to it forcefully and without undue restraint or unearned respect-strike us as more pertinent to today's context. The threat of "an inflated notion of judicial supremacy" asserting arbitrary powers of detention but from the conservative members of the Court. Perhaps liberals should take a page from the Gingrich position paper ${ }^{293}$ and consider bills to limit the Court's jurisdiction in those cases where its conservative instincts are most overreaching. At the very least, one telling response to a rogue is to expose it. Cases like Beach Renourishment deserve to be treated first and foremost, not as objects of respectful analysis, but as symptoms of a pathology.

289. See, e.g., Michael D. Shear, Republican Candidates Cram in Events with Voters Before Break for the Holidays, N.Y. Times, Dec. I8, 201 I, at A34 (discussing Newt Gingrich's claims that "activist liberal judges... [should] be brought before Congress to explain their rulings"); George F. Will, The Absurdity of Eight-Sided Debate: How About a Debate of Substance?, WASH. Post, Nov. 6, 20I I, at A2 I (noting that "Rick Santorum wants to 'eliminate' the often liberal gth Circuit Court of Appeals"). 290. Cf. Bruce Ackerman, Off Balance, in BUSH V. GORE, supra note 278, at 209 (fearing that "[n]othing good" can come from confrontation between the political branches and the Court).

291. Nat'l Fed. of Indep. Bus. v. Sebelius, 132 S. Ct. 2566, 2642 (2012) (Scalia, Kennedy, Thomas, Alito, JJ., dissenting).

292. Boumediene v. Bush, 553 U.S. 723, 842 (2008) (Scalia, J., dissenting).

293. NEWT, supra note 7. 